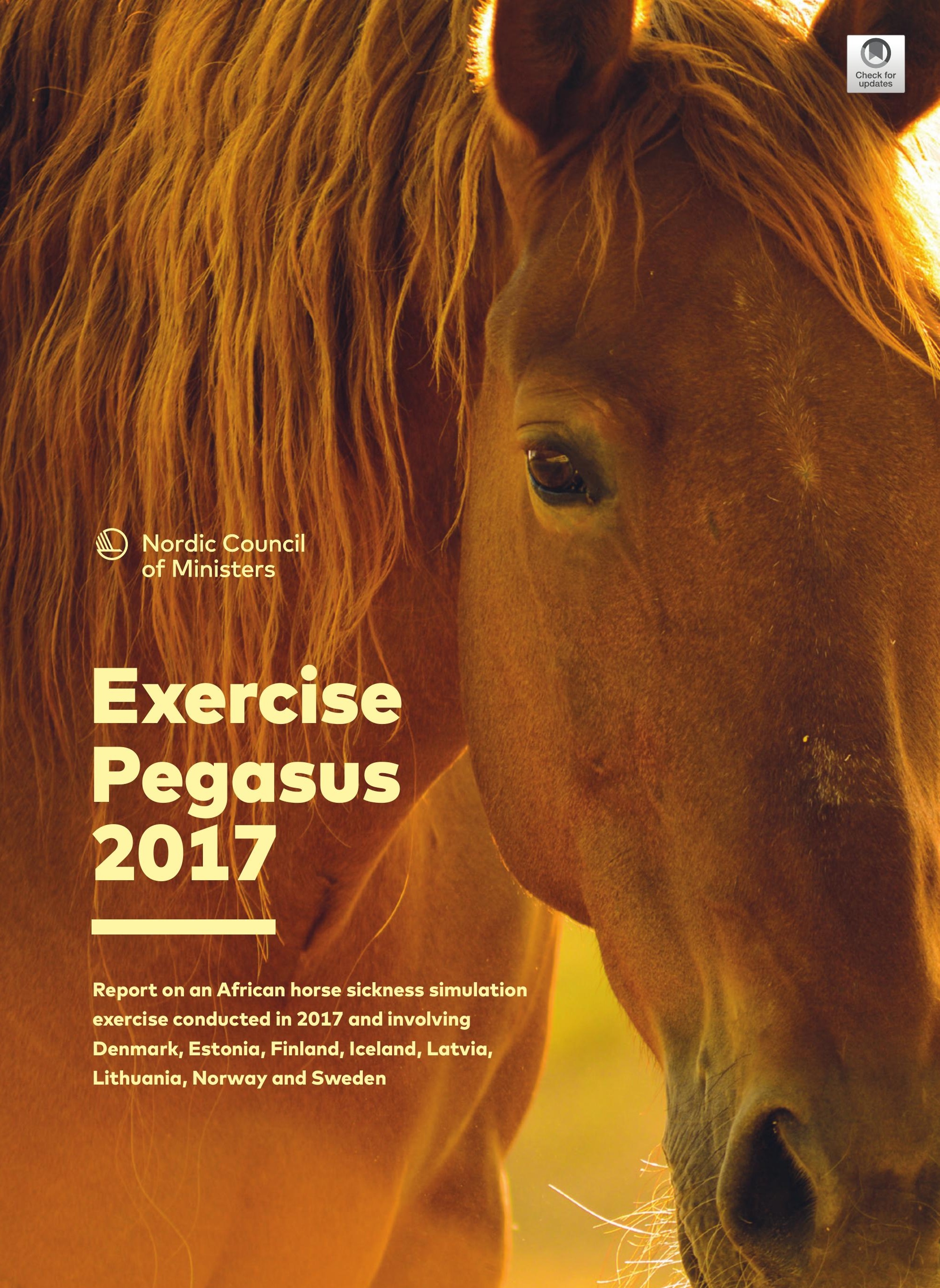





\section{Exercise Pegasus 2017}

Report on an African horse sickness simulation exercise conducted in 2017 and involving Denmark, Estonia, Finland, Iceland, Latvia, Lithuania, Norway and Sweden

Anna Huda, Fred Landeg and Jørgen M. Westergaard

TemaNord 2018:526 


\section{Exercise Pegasus 2017}

Report on an African horse sickness simulation exercise conducted in 2017 and involving Denmark, Estonia, Finland, Iceland, Latvia, Lithuania, Norway and Sweden

Anna Huda, Fred Landeg and Jørgen M. Westergaard

ISBN 978-92-893-5604-6 (PRINT)

ISBN 978-92-893-5605-3 (PDF)

ISBN 978-92-893-5606-o (EPUB)

http://dx.doi.org/10.6027/TN2018-526

TemaNord 2018:526

ISSN $0908-6692$

Standard: PDF/UA-1

ISO 14289-1

(c) Nordic Council of Ministers 2018

Cover photo: Unsplash.com

\section{Disclaimer}

This publication was funded by the Nordic Council of Ministers. However, the content does not necessarily reflect the Nordic Council of Ministers' views, opinions, attitudes or recommendations.

\section{Rights and permissions}

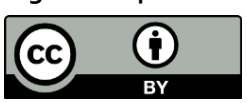

This work is made available under the Creative Commons Attribution 4.0 International license (CC BY 4.0 ) https://creativecommons.org/licenses/by/4.0

Translations: If you translate this work, please include the following disclaimer: This translation was not produced by the Nordic Council of Ministers and should not be construed as official. The Nordic Council of Ministers cannot be held responsible for the translation or any errors in it.

Adaptations: If you adapt this work, please include the following disclaimer along with the attribution: This is an adaptation of an original work by the Nordic Council of Ministers. Responsibility for the views and opinions expressed in the adaptation rests solely with its author(s). The views and opinions in this adaptation have not been approved by the Nordic Council of Ministers. 
Third-party content: The Nordic Council of Ministers does not necessarily own every single part of this work. The Nordic Council of Ministers cannot, therefore, guarantee that the reuse of third-party content does not infringe the copyright of the third party. If you wish to reuse any third-party content, you bear the risks associated with any such rights violations. You are responsible for determining whether there is a need to obtain permission for the use of third-party content, and if so, for obtaining the relevant permission from the copyright holder. Examples of third-party content may include, but are not limited to, tables, figures or images.

Photo rights (further permission required for reuse):

Any queries regarding rights and licences should be addressed to:

Nordic Council of Ministers/Publication Unit

Ved Stranden 18

DK-1061 Copenhagen K

Denmark

Phone +4533960200

pub@norden.org

\section{Nordic co-operation}

Nordic co-operation is one of the world's most extensive forms of regional collaboration, involving Denmark, Finland, Iceland, Norway, Sweden, and the Faroe Islands, Greenland and Åland.

Nordic co-operation has firm traditions in politics, economics and culture and plays an important role in European and international forums. The Nordic community strives for a strong Nordic Region in a strong Europe.

Nordic co-operation promotes regional interests and values in a global world. The values shared by the Nordic countries help make the region one of the most innovative and competitive in the world.

The Nordic Council of Ministers

Nordens Hus

Ved Stranden 18

DK-1061 Copenhagen K, Denmark

Tel.: +4533960200 www.norden.org

Download Nordic publications at www.norden.org/nordpub 



\section{Contents}

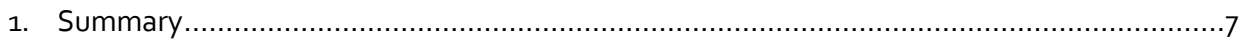

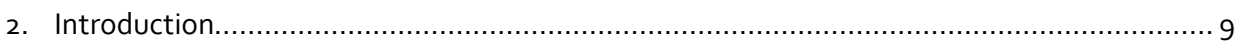

3. Pegasus 2017 exercise - preparation and implementation at a glance .............................11

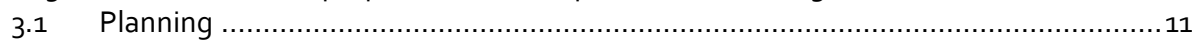

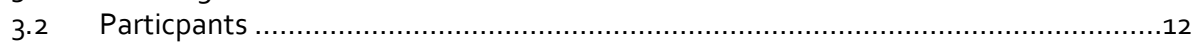

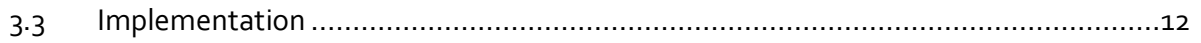

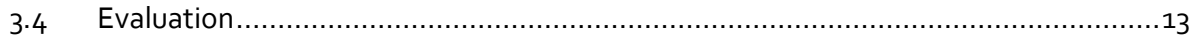

4. The horse population in the Nordic-Baltic region and animal health ..........................15

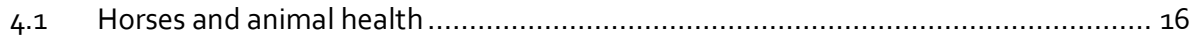

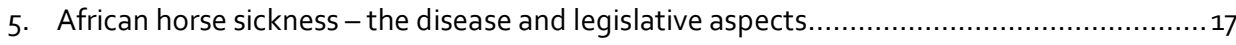

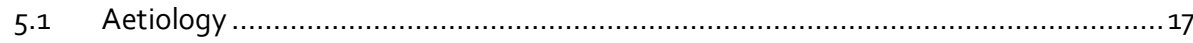

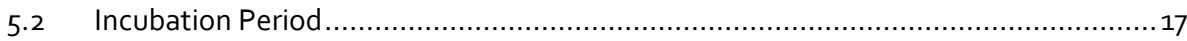

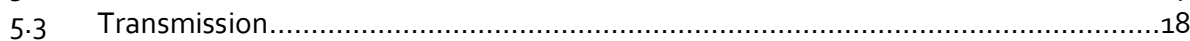

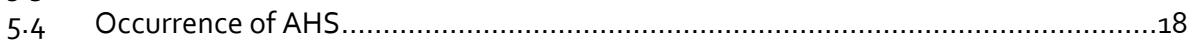

$5.5 \quad$ Legislation and disease control measures ....................................................

6. Pegasus 2017 - The Project Initiation Document (PID) ..........................................21

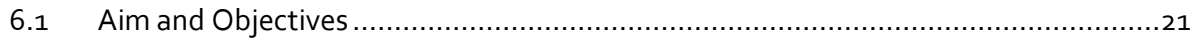

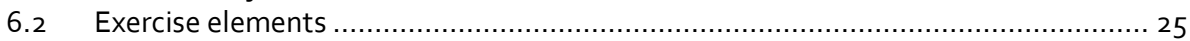

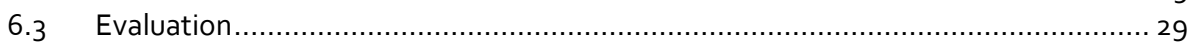

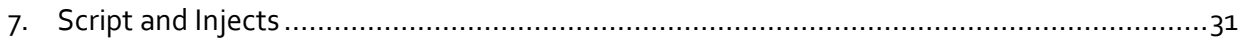

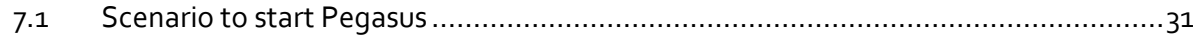

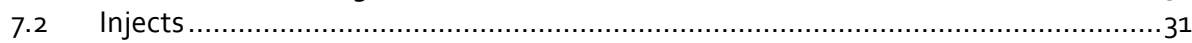

7.3 Numbered prepared injects for the implementation of Pegasus $2017 \ldots \ldots \ldots \ldots \ldots \ldots \ldots . . .32$

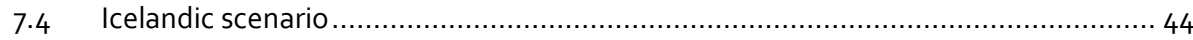

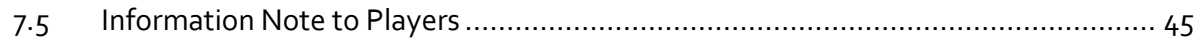

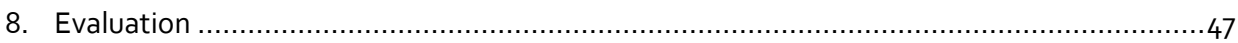

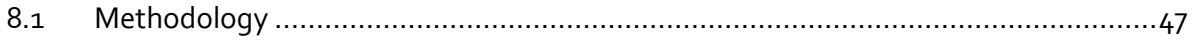

8.2 Analysis of National Evaluator Questionnaires ............................................... 47

8.3 Principal Lessons and Recommendations ..................................................... 50

8.4 Summary Tables of National Evaluator Returns............................................. 51

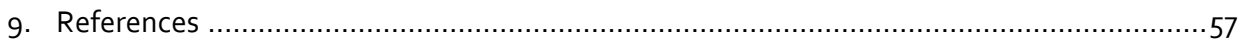

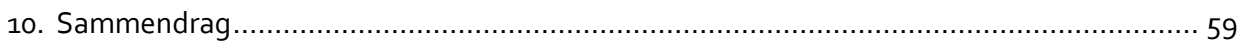

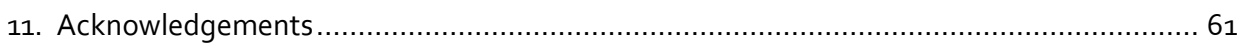

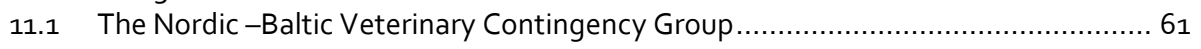





\section{Summary}

The Nordic Baltic countries are free of many of the major infectious diseases that plague the equine sector in many parts of the world. To maintain this privileged health status veterinary administrations, horse owners and practising veterinarians need to be vigilant and consider exotic diseases when confronted with outbreaks of disease in horses. To enhance vigilance against exotic diseases all Nordic and Baltic countries have developed and adopted Contingency plans for African horse sickness, a vector borne viral disease. A very valuable tool for testing contingency plans is simulation exercises and a Nordic-Baltic African horse sickness simulation exercise was conducted in September 2017. The objectives included:

- to test the African horse sickness contingency plans in the Nordic Baltic countries;

- to further develop the communication system established between the veterinary administrations of the Nordic Baltic Countries;

- to improve the knowledge about African horse sickness and disease control measures;

- to improve the crisis communication between the Nordic-Baltic Countries and when to communicate with the public then to do it correctly, clear, relevant and consistently.

African horse sickness (AHS) was chosen for the simulation exercise as AHS with respect to the infectious agent and vector is very similar to bluetongue (BT), a noncontagious, insect transmitted, viral disease of ruminants which since 2007 caused major problems in several countries in Northern Europe including Denmark. Since 2007, BT has been recorded in Norway and Sweden.

The simulation exercise was planned by the Nordic-Baltic Veterinary Contingency Group (N-B VCG) and conducted on 6th September 2017. It covered a number of activities related to:

- Inter-Nordic-Baltic issues.

- National issues.

An independent evaluator was appointed for the evaluation of the Inter-Nordic-Baltic aspects of the simulation exercise and each participating country appointed one or more national evaluators to evaluate both the Nordic - Baltic international issues and the national aspects of the exercise from their country's perspective.

The evaluation dealt with communication during disease suspicion and confirmation, technical aspects of controlling and eradicating African horse sickness, 
involvement of stakeholders, the views of exercise participants and future training of personnel. The results of the evaluation highlight the value of conducting multi-country simulation exercises and that information on a country's communication strategy should be a part of animal health contingency plans. 


\section{Introduction}

The Nordic Council of Ministers - the official body for Nordic intergovernmental cooperation - adopted in 2006 a strategy plan which included cooperation within Nordic-Baltic veterinary contingency planning. The aim of the plan was to maximize the potential of Nordic/Baltic cooperation and work together to prevent and combat serious contagious animal diseases such as foot and mouth disease, avian influenza, classical swine fever, Newcastle disease and any other animal disease, including zoonoses. Within the framework of the strategy plan the Veterinary Administrations have established a Nordic - Baltic Veterinary Contingency Group (N-B VCG), which has focus on a common approach on disease prevention and disease preparedness at farm, regional, national and the Nordic-Baltic level. The activities carried out have included seminars, workshops, simulation exercises and ad-hoc meetings.

The Nordic-Baltic Veterinary Contingency Group, regarding administrative aspects, reports to the Nordic working group for microbiology and animal health/animal welfare See Figure 5: Organisational Chart, page 62.

The objectives of the N-BVCG include:

- To improve cooperation, communication and exchange of information and experiences, between the veterinary authorities within the Nordic-Baltic region, in the context of contingency planning and during animal diseases crises.

- To increase awareness among professionals and stakeholders within the region regarding animal health threats and emerging diseases.

African horse sickness (AHS), a viral disease of equine (horses, zebras, donkeys and mules), is characterized in susceptible horses by fever and clinical signs associated with respiratory and circulatory impairment. The mortality rate in horses may reach $95 \%$. Globalization and climate changes have called for an up-scaling of disease preventive measures and increased disease preparedness with regard to the horse sector in the Nordic and Baltic countries.

With the aim to test AHS contingency plans prepared by the Nordic-Baltic countries, an AHS simulation exercise was carried out in 2017. This report describes the development, planning, execution and evaluation of the exercise codenamed: "Pegasus 2017". 



\section{Pegasus 2017 exercise - preparation and implementation at a glance}

The preparation and implementation of a simulation exercise involving several countries is a rather time consuming but important activity in contingency planning. Several types of simulation exercises are well defined by the European Centre for Disease Prevention and Control (European Centre for Disease Control, 2014). The two main categories are (a) Discussion-based exercise and (b) Operation-based exercise. It was decided at an early stage (2015) to implement an operational-based exercise. During the preparatory work it was agreed that the exercise should be codenamed "Pegasus 2017" and that it should be an organized and controlled scenario-driven functional exercise. It should in general terms:

- Test multiple functions of the national contingency plans covering African horse sickness.

- Test the capability of the Nordic-Baltic veterinary administrations to respond to a disease emergency situation.

- Focus on the interaction and coordination of the veterinary administrations of the Nordic-Baltic countries concerning measures related to disease suspicion and disease outbreaks.

\subsection{Planning}

During the initial meeting of the project team, The Nordic-Baltic Veterinary Contingency Group (N-B VCG), the greatest attention to the simulation exercises was given to:

- Aim.

- Objectives.

- Time frame.

- Scenario and epidemiological links. 
The details of the exercise are given in Pegasus 2017 - The Project Initiation Document (PID) on page 21.

The objectives of Pegasus 2017 were split into two major parts dealing with issues to be handled at:

- Inter-Nordic - Baltic level.

- National level of the participating countries.

The date(s) for the simulation exercises was established early on during the preparatory work in an attempt to ensure that key persons such as Chief Veterinary Officers (CVO), Chairmen of organizations covering the interest of the horse sector could reserve the dates for the simulation exercise. The content of the exercise however was only known by the N-B VCG.

The scenario and epidemiological links during the simulation exercise should to be realistic and challenging, and it was agreed to assume that:

- A warm month of August and early September might increase vector activity.

- The International Equestrian Federation (FEI) event in late august 2017 in Gothenburg would result in many movements of horses.

\subsection{Particpants}

The participants should be representatives from: the central, regional and local veterinary administrations of all Nordic-Baltic countries, practising veterinarians, horse breeders' organizations, transporters of horses and others involved in the work carried out by the horse industry.

\subsection{Implementation}

As Pegasus 2017 was to be an inject-driven exercise, it was agreed that the facilitating or directing staff (Distaff) should ensure the flow of the activities of the exercise. Messages (injects) should be sent to the exercise players using various communication means outlined in the national contingency plans. The exercise players were expected to respond to messages received from the Distaff within the framework of their contingency plan and transmit relevant information to the other players along with copies of the messages to the Distaff. Such procedures would make it possible for the Distaff to oversee the exercise operation and to intervene if deemed necessary. Guidelines for work to be carried out by the Distaff and templates for injects are listed in Pegasus 2017 - The Project Initiation Document (PID) on page 21. 


\subsection{Evaluation}

The N-B VCG agreed at an early stage that an independent evaluator should be appointed for the preparation and completion of the evaluation of the Inter-Nordic-

Baltic activities and for providing assistance in relation to the evaluation of activities carried out at national levels. 



\section{The horse population in the Nordic-Baltic region and animal health}

Different breeds of horses have in the past evolved in the Nordic-Baltic countries depending on the environmental conditions and the use of horses. About 100 years ago horses were still vital in agriculture, industry, transport and the military; but the introduction of modern technology in many areas has replaced horses by machinery and equipment and reduced the horse population. However, today horses continue to be of economic importance in many countries in relation to sport activities, as companion (pet) animals, working animals and maintaining natural reservoirs. In general, the use of horses is more varied than may be anticipated at a first glance and during the past decade the number of horses per capita has remained relatively constant (Liljenstolpe, 2009). Within the area of sport, the International Equestrian Federation (FEI) organizes each year about 250 international competitions, which results in extensive transport of horses across country borders.

With regard to the horse population in the Nordic-Baltic countries it is difficult to obtain an exact number on how many horses live in studs, fields and barns. Information obtained from national veterinary administrations, based on data from national horse registers or estimates, indicate that the horse population in the 8 countries is about 800,000 ; see Table 1: Estimated Horse Population in the NordicBaltic Countries.

Table 1: Estimated Horse Population in the Nordic-Baltic Countries

Note: Numbers are from national registers and estimated. Many National Registers do not record deaths or the export of an animal, and not all horses may be registered.

Source: Veterinary Administrations. 


\subsection{Horses and animal health}

Most horse diseases are subjected to passive surveillance and a number of diseases are listed as notifiable by the National Veterinary Authorities to the World Organization for Animal Health (OIE) and to the European Commission via the Animal Disease Notification System (ADNS) (European Commission, 1982). The list of notifiable horse diseases includes African horse sickness, contagious equine metritis, dourine, equine encephalomyelitis, equine infectious anaemia, equine influenza, equine piroplasmosis, equine rhinopneumonitis, equine viral arteritis, glanders and Venezuelan equine encephalomyelitis. These diseases are considered as exotic in the Nordic-Baltic region. In preparation for outbreaks of African horse sickness (AHS), all Nordic and Baltic countries have adopted legislation and contingency plans.

The laboratory diagnosis of AHS is carried out at National AHS Reference laboratories and often in cooperation with the EU Reference Laboratory for African horse sickness. The diagnosis is based on the identification of infectious virus, virus nucleic acid, viral antigens or specific antibodies. The EU Reference Laboratory conducts regularly Ring Trials with the participation of National Reference laboratories. 


\section{African horse sickness - the disease and legislative aspects}

African horse sickness (AHS) is listed by the World Organisation for Animal Health (OIE) as a notifiable disease. It is an acute or sub-acute insect-borne viral disease of horses and other equines. In susceptible horses, the disease is characterized by depression, respiratory and circulatory impairment. The mortality rate may approach $100 \%$. AHS is caused by an orbivirus and there are 9 different serotypes which can be differentiated by diagnostic tests. The disease is transmitted by midges; hence outbreaks tend to be seasonal. In 2007-2009, the Culicoides midges caused the spread of the bluetongue in cattle and sheep in Northern Europe including Denmark, Norway and Sweden. The Culicoides midges are also the main vectors and transmitters of AHS.

The OIE list of differential diagnosis includes anthrax, equine infectious anaemia, equine viral arteritis, equine encephalosis, piroplasmosis and Hendra virus infections.

\subsection{Aetiology}

The virus of AHS belongs to the family Reoviridae of the genus Orbivirus and the source of virus include:

- Viscera and blood of infected horses.

- Semen, urine and nearly all secretions during viraemia, but no studies have documented transmission.

- Viraemia usually lasts $4-8$ days in horses but may extend up to 21 days; in zebras, viraemia may last up to 40 days.

- Recovered animals do not remain carriers of the virus.

\subsection{Incubation Period}

Usually 7-14 days; but may be as short as 2 days. 


\subsection{Transmission}

- Not contagious by contact.

- Usual mode of transmission is the biological vector Culicoides spp. C. imicola and C. bolitinos are known to transmit AHS virus in the field; $C$. imicola appears to be the principal vector.

- The North American species C. variipennis is an efficient vector in the laboratory.

- Occasional mode of transmission: mosquitoes - Culex, Anopheles and Aedes spp.; ticks - Hyalomma, Rhipicephalus; and possibly biting flies - Stomoxys and Tabanus.

- Moist mild conditions and warm temperatures favour the presence of insect vectors.

- Wind has been implicated in dispersal of infected Culicoides in some epidemics.

- Movement of Culicoides spp. over long distances (700 kilometres over water, 150 kilometres over land) via wind has been postulated sources of virus.

\subsection{Occurrence of AHS}

AHS is endemic in the central tropical regions of Africa, from where it spreads regularly to Southern Africa and occasionally to Northern Africa.

The disease was diagnosed in Spain in September 1987 after being absent for 21 years. Once the disease was confirmed the control measures included a large vaccination programme, vector controls and regionalization with movement restrictions. The outbreaks recorded in Spain were caused by serotype 4 and occurred from 1987-1990. In 1989, the disease was also recorded in Portugal, and a total of 100 outbreaks were reported.

\subsection{Legislation and disease control measures}

AHS is notifiable in the EU in accordance with the provisions of Council Directive 82/894/EEC of 21 December 1982 (European Commission, 1982) on the notification of animal diseases within the Community.

The legal provisions related to control and eradication measures are given in Council Directive 92/35/EC of 29 April 1992 (European Commission, 1992) laying down rules and measures to combat AHS. The provisions of the legislation include:

- Where an outbreak of AHS is confirmed all infected equidae have to be killed and the carcasses of the animals disposed of. The measure taken on the holdings concerned shall also be extended to all holdings situated within a 20 kilometres radius; an epidemiological survey shall be carried out and possibly vaccination. 
- The competent authority must establish a protection zone (of at least 100 kilometres around the infected holding) and a surveillance zone (of at least 50 kilometres beyond the protection zone), in which certain specific measures are applied. These measures include: identifying all holdings containing equidae, visits and examinations carried out by the official veterinarian and a ban on moving the animals.

- Each Member State designates a national laboratory responsible for carrying out the tests laid down in the Directive, and then informs the other Member States and the public of the laboratory's contact details. Each national laboratory is required to liaise with the Community reference laboratory which is located in Algete, Madrid, Spain.

With regard to trade in horses a reference is made to the provisions of Council Directive 90/425/EEC of 26 June 1990 concerning veterinary and zootechnical checks applicable in intra-Community trade in certain live animals and products with a view to the completion of the internal market. 



\section{Pegasus 2017 - The Project Initiation Document (PID)}

During the preparatory work the Nordic-Baltic veterinary Contingency Group prepared a Project Initiation Document (PID) and the main content of the document is given below.

\subsection{Aim and Objectives}

\subsubsection{Aim of Pegasus 2017}

- To test the African horse sickness (AHS) contingency plans in the Nordic-Baltic countries.

- To further develop the communication system established between the veterinary administrations of the Nordic-Baltic countries.

- To improve the knowledge about AHS and disease control measures.

- To improve the crisis communication between the Nordic-Baltic countries and when to communicate with the public then to do it correctly, clear, relevant and consistently.

\subsubsection{Objectives for the Pegasus 2017 exercise}

To comply with the wishes of veterinary administrations and stakeholders during the exercise it was decided to have in the PID a clear definition of the objectives to be applicable for all participants involved at international level and separate objectives to take into account the needs of individual countries.

\subsubsection{Objectives and indicators at international level}

- The veterinary administrations in the Nordic-Baltic countries share information with each other and all relevant stakeholders. This is done by making the information available, by receiving and by requesting information. 
- The Chief Veterinary Officer (CVO) in the affected country should inform the CVOs within a reasonable time frame in an appropriate manner by using different communication means such as telephone conference, videoconference, e-mail, websites, and SMS (Short Message Service) for the purpose of up-dating communication and information sharing plans.

- The operational staff, involved in the prevention and control of exotic animal diseases and issues related to trade in live animals and products of animal origin, should be in contact with each other within a reasonable time frame in an appropriate manner.

- There should be an updated joint document in use with contact information (telephone numbers and e-mail addresses) regarding the CVO functions, including Deputy CVOs, in the Nordic and Baltic countries.

- A joint conference is to be conducted during the exercise. All countries participate.

- The veterinary administrations coordinate information in order to make it correct, clear and relevant when communicating with horse owners, the public and media.

- The information is correct and coordinated in such a way that it does not contain any contradictory information.

- Information is distributed in different ways, suitable for the target groups (horse owners, the public, veterinarians etc.).

- The information should be written also in English. The objectives for interNordic-Baltic AHS simulation exercise are listed in Table 2: Proposed objectives at inter-Nordic-Baltic level for AHS exercise, on page 23. 
Table 2: Proposed objectives at inter-Nordic-Baltic level for AHS exercise

\begin{tabular}{|c|c|}
\hline Country & $\begin{array}{l}\text { Proposed objectives at inter-Nordic-Baltic level for an African horse sickness simulation exercise } \\
\text { conducted in } 2017\end{array}$ \\
\hline Denmark & $\begin{array}{l}\text { The Danish Veterinary and Food Administration participate in meetings with other Nordic-Baltic } \\
\text { veterinary authorities as planned. } \\
\text { The Danish Veterinary and Food Administration provide information on suspected cases/outbreaks of } \\
\text { AHS to other Nordic-Baltic veterinary authorities. }\end{array}$ \\
\hline Estonia & $\begin{array}{l}\text { To test communication system established between the veterinary administrations of the Nordic Baltic } \\
\text { Countries. } \\
\text { To test the part of African horse sickness contingency plan. } \\
\text { To improve the knowledge about African horse sickness and disease control measures. }\end{array}$ \\
\hline Finland & $\begin{array}{l}\text { To test communication system established between the veterinary administrations of the Nordic and } \\
\text { Baltic Countries. } \\
\text { To assess possible means of creating coherent information to stakeholders about disease incidents } \\
\text { affecting several Nordic and Baltic countries. }\end{array}$ \\
\hline Iceland & $\begin{array}{l}\text { The Icelandic Food and Veterinary Authority (MAST) participates in meetings with NB vet. authorities. } \\
\text { Providing information about local suspected cases of a serious horse illness and consider whether there is } \\
\text { any connection with the ongoing outbreak in Sweden. }\end{array}$ \\
\hline Latvia & $\begin{array}{l}\text { To test communication system established between the veterinary administrations of the Nordic and } \\
\text { Baltic Countries. } \\
\text { To exchange information and participate in meetings between Nordic Baltic countries. }\end{array}$ \\
\hline Lithuania & $\begin{array}{l}\text { The representatives of State Food and Veterinary Service of Lithuania will participate in meetings with } \\
\text { other Nordic-Baltic veterinary authorities as planned. } \\
\text { The State Food and Veterinary Service of Lithuania will provide information on suspected } \\
\text { cases/outbreaks of AHS to other Nordic-Baltic veterinary authorities. }\end{array}$ \\
\hline Norway & $\begin{array}{l}\text { To test early warning systems and the ability to participate in meetings between the other Nordic-Baltic } \\
\text { countries. } \\
\text { To exchange information between the Nordic-Baltic countries and to produce coordinated information. }\end{array}$ \\
\hline Sweden & $\begin{array}{l}\text { To test the African horse sickness contingency plan. } \\
\text { To further develop the communication system established between the veterinary administrations of the } \\
\text { Nordic-Baltic Countries. } \\
\text { To improve the knowledge about African horse sickness and disease control measures. } \\
\text { To improve the crisis communication between the Nordic-Baltic Countries and when to communicate } \\
\text { with the public then to do it correctly, clear, relevant and consistently. }\end{array}$ \\
\hline
\end{tabular}

\subsubsection{Objectives at national level}

To give participants of the participating countries during an animal disease emergency simulation an opportunity to re-examine the value of the existing contingency plan The indicators relate to the objectives developed by individual countries are listed Table 3: Proposed objectives and indicators for National AHS exercise, page 24. 
Table 3: Proposed objectives and indicators for National AHS exercise

Country Proposed objectives and indicators for National African horse sickness simulation exercise to be conducted in 2017

Denmark To provide information to stakeholders (horse owners, the public, veterinary practitioners etc.) on AHS facts on the disease, the animal health status regarding AHS in DK and in the N-B countries, and the consequences of this health status to the stakeholders.

To expose field staff in one region to a simulated AHS suspicion, and in two regions to a simulated AHS outbreak.

To obtain from staff in three different regions a proposal concerning the most preferred method to euthanize horses under field conditions.

To test the usefulness of the epidemiological questionnaire prepared for animal health emergency situations in the horse sector.

Estonia To test part of AHS contingency plan: setting up the quarantine and restrictions in the suspected farm.

Finland To test and evaluate the AHS contingency plan especially in regard of a disease control strategy.

To increase level of knowledge on AHS among both competent authority and horse owners.

Iceland To test communication and collaboration between district veterinary officers and central veterinary authority.

To test the sampling procedure by DVO and packing and sending of samples by national laboratory intended for testing for AHS/serious foreign horse diseases.

To test contingency plan for foreign animal diseases specifically with regards to epidemiological measures to be taken, such as zoning and collection of animal health status and data (postponed).

Latvia To test the AHS contingency plan, particularly the actions to be taken by official veterinarians in case of AHS suspicion.

To organize the seminar for veterinary practitioners dealing with horses and official veterinarians on AHS.

Lithuania To inform the State Food and Veterinary Service staff regarding AHS and to test the part of contingency plan regards the epidemiological measures and culling and destruction procedures.

Norway To increase the level of awareness and knowledge of AHS in the NFSA and among private veterinarians, the horse industry and horse owners. Indicator: The number of participants in the AHS seminar and in the exercise.

To test the crisis communication in the authority, with stakeholders and the public.Indicators: Early warning systems and reporting obligations must be followed. First information out externally within 2 hours, followed by correct, clear and balanced information updates.

To test the preparedness for field work in an outbreak situation in all regions. Indicators: A crisis team must be ready for departure from the office within one hour with the necessary equipment. Established procedures must be followed on the farm.

To test our new incident management tool MatCIM Indicators: All procedures for early warning, cooperation, exchange of information and reporting must be done in MatCIM

Sweden The Swedish Board of Agriculture has a good ability to collaborate with relevant countries, authorities and organizations to achieve coordination.

The Swedish Board of Agriculture has a good ability to share information, both externally and internally, by making relevant information available and by receiving and requesting information.

The Swedish Board of Agriculture has a good ability to coordinate information with stakeholders in order to be clear and relevant in communication with horse owners, the public and media. 


\subsection{Exercise elements}

\subsubsection{Exercise scope/type}

Initially, an alert exercise at Nordic-Baltic level turning into different simulation exercise at country level which take into account the specific national objectives such as drills, table-top exercises and full-scale exercises.

\subsubsection{Duration of exercise}

The exercise will be designed in such a way that:

- The veterinary administration of all the Nordic and Baltic countries will be available on a preannounce date (Wednesday 6th September 2017).

- Individual countries can increase the duration as found desirable and reflecting the national objectives.

\subsubsection{Exclusions}

Exclusions will depend on National objectives and requirements.

\subsubsection{Deliverables and Outcomes}

The deliverables and outcomes will be measured by evaluation of simulation exercise activities. The actions to measure the exercise results include:

- Evaluation of activities by an external evaluator.

- Evaluations made by observers.

- Evaluations made by participants of the exercise.

Information on observations made and evaluation carried out during the simulation exercise will be presented in a report and possibly also during a seminar.

Individual countries may list special requirements related to deliverables and outcomes.

Veterinary administrations may make use of the outcome concerning an up-dating of the existing AHS contingency plan.

\subsubsection{Interfaces/Dependencies/Partners}

The exercise will examine the communication between the veterinary administrations in the Nordic and Baltic countries. 
The Nordic-Baltic Veterinary Contingency Group (N-B VCG) shall draw-up the scenario and develop the exercise injects. The members will be the directing staff (Distaff) and be in close contact during the exercise.

The partners should include veterinarians working in veterinary practices involved in prevention and control of animal health problems in horses and persons involved in the management of horse stud books and horse shows.

\subsubsection{Finance plan}

The N-B VCG financial plan will include allocations related to:

- Observers.

- Evaluation.

- Printing of report

- Individual countries take care of own expenditures.

\subsubsection{Communication plan}

Copies of all communication shall be placed in one mailbox.

Information about the simulation exercise shall be announced to:

- The European Commission.

- The EFTA Surveillance Authority (ESA).

- The World Organisation for Animal Health, OIE.

\subsubsection{Scenario}

The scenario prepared for the international aspects of the simulation exercise is described in N-B VCG Chapter 7 Script and Injects, page 31. Basically, AHS was confirmed in a horse in Sweden on 6th September 2017, and the horse had taken part in the FEl European Champions held from 21st - 27th August in Gothenburg.

\subsubsection{Scenarios by individual countries}

The scenarios developed by individual countries will be based on the above text.

\subsubsection{Injects by participating countries}

Injects prepared for Pegasus 2017 are listed in Chapter 7 Script and Injects, page 31, and the inject form to be used is shown in Table 4, see page 27. 
Table 4: Inject message format

Inject Message Heading

Date/Time

Inject Number

From (Initiator)

Sent on behalf of

To (receiver/responder)

Method (Phone, email, website, other)

Title of Pegasus 2017 Message

Content

Objective

Expected reaction

Observed reaction

Comments

\subsubsection{Guidelines for Players and Directing staff}

\section{Players}

The players are persons who during animal disease emergencies are designated to take part in application of measures to prevent, control and eradicate infectious diseases.

The job of the players is to respond as they would in a real emergency to the messages that they receive during the simulation exercise, see Figure 1: The relationship between the players, injects to and from the simulated world and injects from directing staff to players.

Figure 1: The relationship between the players, injects to and from the simulated world and injects from directing staff to players

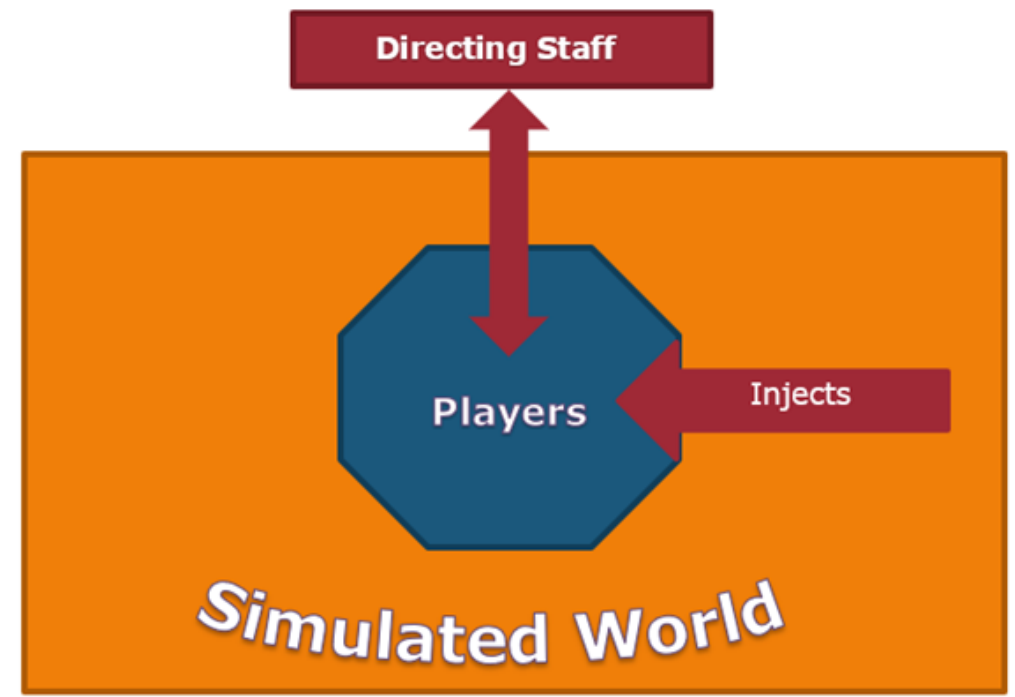

Each country shall prepare guidelines/instructions of importance for the implementation of the simulation exercise. Such information could cover the use of emails etc. 


\section{Directing staff}

During the exercise the members of the Nordic-Baltic Veterinary Contingency Group work as directing staff (Distaff) and coordinators. The Distaff know the scenario and the time of the events and have different tasks to perform during the exercise such as:

- Monitor the progress of the exercise and intervene if necessary.

- Coordinate the progress of the exercise.

- Liaise and up-date the Evaluator on on-going events during the simulation exercise.

- Draw up a preliminary exercise report for each country.

- Staying in close contact with Distaff in all participating countries.

The injects prepared for the events of the exercise shall be compiled in a separate "Inject document". The document shall be available to all Distaff.

It is important that the Distaff make sure that the players acknowledge the receipt of messages and all emails are sent cc. to the Distaff mail address:

- When sending international injects the sender should always send a copy to:

- the Distaff in the receiving country or countries;

- the independent evaluator: Fred Landeg. E-mail: fred.landeg@btinternet.com;

- an agreed common mailbox created for the exercise: nbvcg@mast.is

The words "this is an exercise" shall appear on all mails.

The names and email addresses and phone numbers of coordinators during the implementation of Pegasus 2017 are shown in Table 5: Name, email addresses and phone numbers of coordinators during the implementation of Pegasus 2017.

Table 5: Name, email addresses and phone numbers of coordinators during the implementation of Pegasus 2017

\begin{tabular}{|c|c|c|c|}
\hline Country & Coordinator & Email addresses & Phone number \\
\hline \multirow[t]{2}{*}{ Denmark } & Anna Huda & anxu@fvst.dk & +4572276521 \\
\hline & Birgitte Beck Jørgensen & brb@fvst.dk & +4572276522 \\
\hline Estonia & Maarja Kristian & maarja.kristian@vet.agri.ee & +3725297324 \\
\hline Finland & Sirpa Kiviruusu & sirpa.kiviruusu@evira.fi & +358400920503 \\
\hline \multirow[t]{2}{*}{ Iceland } & Sigridur Gisladottir & Sigridur.gisladottir@mast.is & \multirow[t]{2}{*}{+3548580805} \\
\hline & Audur Arnthorsdottir & Audur.arnthorsdottir@mast.is & \\
\hline Latvia & Māra Užule-Spriṇge & Mara.uzule-springe@pvd.gov.lv & +37167095256 \\
\hline Lithuania & Marius Masiulis & marius.masiulis@vmvt.lt & +37052404340 \\
\hline Norway & Siri Løtvedt & simlo@mattilsynet.no & +4795408855 \\
\hline \multirow[t]{2}{*}{ Sweden } & Anders Landgren & Anders.landgren@jordbruksverket.se & $+4636-155927$ \\
\hline & Cecilia Davelid & Cecilia.davelid@jordbruksverket.se & $+4670-8758665$ \\
\hline
\end{tabular}


The names and email addresses and phone numbers of Chief Veterinary Officers (CVOs) during the implementation of Pegasus 2017 are shown in Table 6: Name, Email addresses and phone numbers of Chief Veterinary officers (CVOs) or acting CVOs during the implementation of Pegasus 2017.

Table 6: Name, Email addresses and phone numbers of Chief Veterinary officers (CVOs) or acting CVOs during the implementation of Pegasus 2017

\begin{tabular}{llll} 
Country & Name CVO & Email & Phone number \\
Denmark & Acting CVO John Larsen & jl@fvst.dk & +4572276680 \\
Estonia & Acting CVO Maarja Kristian & maarja.kristian@vet.agri.ee & +3725297324 \\
Finland & Taina Aaltonen & Taina.aaltonen@mmm.fi & +358295162439 \\
Iceland & Sigurborg Dadadottir & Sigurborg.dadadottir@mast.is & +3548580815 \\
& Acting CVO Audur Arnthorsdottir & Audur.arnthorsdottir@mast.is & \\
Latvia & Maris Balodis & Maris.balodis@pvd.gov.lv & +37167095230 \\
Lithuania & Darius Remeika & Darius.Remeika@vmvt.lt & +37052404361 \\
Norway & Acting CVO Ole-Herman Tronerud & ohtro@mattilsynet.no & +4741459845 \\
Sweden & Ingrid Eilertz & Ingrid.eilertz@jordbruksverket.se & $+4670-6362153$ \\
\hline
\end{tabular}

\subsubsection{Success criteria and evaluation}

The success criteria shall include the quality and speed of information transmission between the veterinary administrations of the Nordic-Baltic countries. In this context it should be recalled that the Nordic-Baltic Veterinary Contingency Plan adopted by the Nordic Council of Ministers in 2006 had the aim, to maximize the potential of Nordic/Baltic cooperation and work together to prevent and combat serious animal diseases such as:

- Foot and mouth disease.

- Avian influenza.

- Classical swine fever.

- Any other animal disease, including zoonoses.

\subsection{Evaluation}

\subsubsection{Evaluation of International level activities}

It was decided at an early stage to appoint an independent evaluator from outside for the evaluation covering the international aspects of the simulation exercise, and $\mathrm{Dr}$ 
Fred Landeg, CBE BVetMed MSc MRCVS, formerly UK Deputy Chief Veterinary Officer and acting UK Chief Veterinary Officer was in 2017 appointed as evaluator.

It was agreed that persons working as evaluators at national level should observe the actions and decisions of the players with the objectives:

- To note to what extend players implement agreed guidelines for Nordic-Baltic cooperation.

- To later report what went well and what did not.

To do this, evaluators should be familiar with the national and inter-national objectives of the simulation exercise, the exercise scenario and the organization of the NordicBaltic veterinary administrations. The duties of the evaluators were to include:

- Measure the time and mode of the contact between the Chief Veterinary Officers (CVO) of the Nordic - Baltic Countries, or their designated staff, after the first disease notification.

- Measure the time and mode of contact between the operational staff in the Nordic-Baltic countries involved in the prevention and control of exotic animal diseases and issues related to trade in live animals and products of animal origin.

- Check that there exists a joint document with updated contact information. If the document exists, is it used?

- Check that a joint conference is conducted:

- Is the joint conference properly announced?

- Who announces the meeting?

- Is there an agenda for the joint conference?

- Who chairs the meeting?

- Is anyone taking notes at the meeting?

- Are the notes distributed to the relevant stakeholders after the meeting?

- Do all the invited countries participate in the meeting?

- Check that the information from the veterinary administrations in the different countries is coordinated.

- Check that the information is distributed in different ways, suitable for the target groups (horse owners, the public, veterinarians etc.).

\subsubsection{Evaluation of National level activities}

Each country shall make arrangements for the evaluation of activities based on the objectives drawn up for national level implementation.

The names of the national evaluators shall be submitted to the team leader of evaluation (lead evaluator) Dr Fred Landeg, email address: fred.landeg@btinternet.com 


\section{Script and Injects}

\subsection{Scenario to start Pegasus}

It is a sunny, warm and slightly breezy day on the26th August in the FEI European Championships 2017. The competitions that started on 21st August have been going on for five days already and now it is time for the last two days of finals and a big ending ceremony. The audience is cheering as shiny horses and their ambitious riders prepare for their last efforts to win in the tough competition.

A Spanish show jumping horse that did not perform on his best possible level is being prepared for leaving for home sooner than planned, after just two days visit to Gothenburg. The minder of the horse gets worried when she notices that the horse seems depressed.

After consulting the owner, she takes the temperature and since it is close to normal, they decide to continue packing. A flight has already been re-scheduled for the same day and it would cost a lot of money to cancel and change it again. After all, the horse was fine the previous day and the official competition veterinarian confirmed its health status.

The flight arrives in Spain after midnight on 27 th and the horse seems tired but not significantly worse, so the minder feels somewhat relieved. However, six days after the flight the horse gets worse and finally becomes severely ill with high temperature and breathing difficulties.

A vet is called on 3 rd September to examine the horse. Five cases of African horse sickness have been detected in Southern Spain during the past seven days, but they are not very close to the home stable of this show jumping horse and thus the veterinarian will not instantly suspect AHS. He takes samples and sends them directly to a diagnostic laboratory.

The samples are investigated on 4 th September and sent to the national reference laboratory where investigation with RT-PCR shows strong evidence of AHS virus infection. At the same time, horses that have participated in the Gothenburg competition have started showing similar symptoms.

\subsection{Injects}

The use of injects is the way to achieve that the events and incidents prepared for the exercise can be communicated to the players. It is by injects that players gradually become familiar with the exercise events and receive on problems to be solved. A master event list is shown in Table 7, while the text of individual injects are given in the completed inject forms numbered 1-11. 
Table 7: Master event list and time schedules for simulation exercise injects and Nordic-Baltic Skype conferences on 6th September 2017

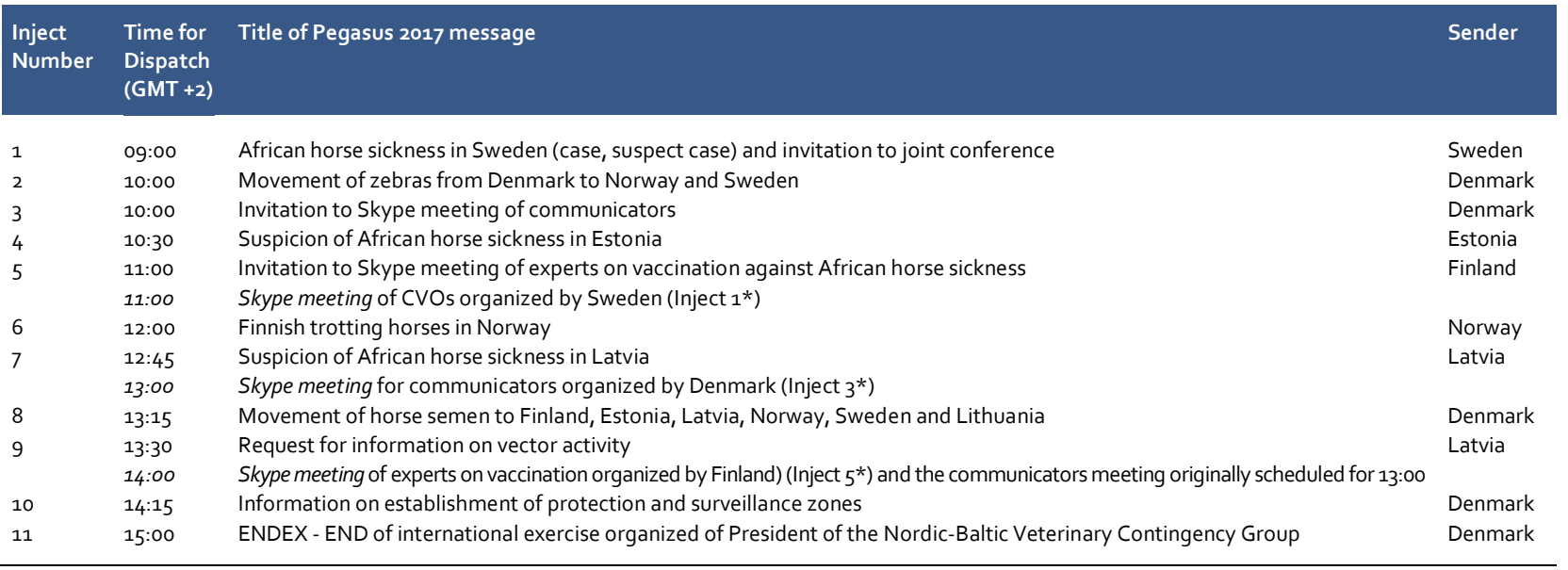

Note: *The countries sending invitations to Skype meetings shall prepare and circulate an agenda for the meeting.

\subsection{Numbered prepared injects for the implementation of Pegasus 2017}

\subsubsection{Inject 1}

Date and Time

6/9/2017 at o9.0o local time Sweden.

\section{From (Initiator)}

The exercise leaders in all countries will forward this inject to their CVO in order to get the exercise started at 09.00 without delay.

On behalf of

Chief Veterinary Officer, Sweden.

To (receiver/responder)

Chief Veterinary Officers in the participating countries; cc: nbvcg@mast.is

Method (Phone, email, website, other)

Email.

\section{Content}

E-mail from the Swedish CVO including:

- First case of African horse sickness (AHS).

- Suspicion of AHS.

- International joint conference today at 11:00 $(G M T+2)$ - invitation. 


\section{First case of AHS}

This morning, the 6th September 2017, the first case of African horse sickness (AHS) in Sweden was confirmed. The infected horse was a 12 years old stallion from a show jumping stable in Ljungby in the south of Sweden. The stallion was euthanized, at the equine clinic in Helsingborg, on 5 th September.

The epidemiological investigation has revealed that the horse took part in the FEI European Championships in Gothenburg (21-27 August).

The horse returned to the home stable on 28th August, and on 2 September the horse came down with a fever $\left(40^{\circ} \mathrm{C}\right)$ and general malaise. It was placed in the isolation (quarantine stable) during the day and then transported to the equine clinic in Helsingborg.

The health situation deteriorated. The symptoms were dyspnea and dilated nostrils with frothy fluid oozing out; edematous swellings, no response to treatments. The horse was euthanized and sampled for AHS. The diagnosis was confirmed by PCR this morning. The show jumping stable has 27 horses and all the other horses appear to be healthy.

\section{Suspicion of AHS}

Yesterday a veterinarian reported a dead horse in a small zoo in Slottsskogen in Gothenburg. The horse had been found dead in the pasture. It had appeared perfectly healthy according to the owners the day before.

The horse was accompanied with two zebras. The zebras were imported to Sweden about 4 weeks ago, still not clear where they came from. The zebras appeared fully healthy at a general clinical examination.

Samples for AHS from the dead horse were admitted yesterday to SVA (National Veterinary Institute). Test results are expected during the day.

\section{Joint conference}

Sweden invites all countries involved to a Skype/phone meeting today, 6 September, at 11:00 (GMT + 2) to exchange information on the disease situation and to initiate the collaboration of prevention and control of the disease. An invitation with more details concerning the meeting will be sent to you as soon as possible.

\section{Objective}

To get the exercise started and provide information on African horse sickness in Sweden.

\section{Expected reaction}

The participating countries will contact Sweden for additional information. They will also contact their national horse sector to investigate to what extent horses have been in Gothenburg for the competition.

Sweden will invite the competent authorities/CVO in all countries for a phone/Skype conference in order to get a good cooperation between the countries. 
7.3.2 Inject 2

Date/hours

6/9/2017 at 10:00.

From (Initiator)

Danish exercise leader.

On behalf of

Danish Veterinary and Food Administration.

To (receiver/responder)

Norway, Sweden; cc: nbvcg@mast.is

Method (Phone, email, website, other)

Email.

Title of Pegasusus2017 message

This is an exercise, Pegasus 2017: Zebras from Denmark to Norway and Sweden.

\section{Content}

Copenhagen Zoo has on $9^{\text {th }}$ August 2017 sent two zebras to Zoo Park in Gothenburg, Sweden and one zebra to the Zoo Park in Kristiansand, Norway.

Further information has been collected telling that a group of eight zebras imported from South Africa arrived at Copenhagen Zoo on zoth July. This consignment included the two zebras sent to Sweden and the one to Norway. At this moment, this is the only information we have.

Best regards, Stig Mellergaard, Animal Health Division, Danish Veterinary and Food Administration

\section{Objective}

Information to Norwegian and Swedish Veterinary Authorities.

Expected reaction

Optional: Contact from Mattilsynet and Jordbruksverket in order to receive specific information on the imports. 
7.3.3 Inject 3

Date/time

6/9/2017 at 10:00.

From (Initiator)

Danish exercise leader.

On behalf of

Chief Veterinary Officer, Denmark.

To (receiver/responder)

All CVOs; cc: nbvcg@mast.is

Method (Phone, email, website, other)

Email.

Title of Pegasusus2017 message

This is an exercise, Pegasus 2017: Invitation to Skype meeting of Communicators on the disease situation.

\section{Content}

Information in different mass media and social media appears greatly to differ from country to country concerning the African horse sickness situation. Some frustration, panic etc. has been observed in the horse sector.

Denmark invite staff from the communication units to discuss the topic at a Skype meeting starting at 13:00 hours with the following agenda:

- 1.

- 2 .

Etc.

Best regards, deputy CVO John Larsen, Animal Health Division, Danish Veterinary and Food Adm.

\section{Objective}

Coordination of information from the authorities from all countries in order to prevent panic and frustration.

\section{Expected reaction}

The participants see the need of a joint conference for the communicators. The communicators develop/agree on a common communication strategy concerning the African horse sickness situation. 
7.3.4 Inject 4

Date/time

6/9/2017 at 10:30.

From (Initiator)

Estonian exercise leader.

On behalf of

Chief Veterinary Officer, Estonia.

To (receiver/responder)

CVO Sweden; cc: nbvcg@mast.is

Method (Phone, email, website, other)

Email.

Title of Pegasusus2017 message

This is an exercise, Pegasus 2017: African Horse Sickness in Estonia.

Content

This morning, the 6th September 2017, the African Horse Sickness (AHS) suspicion in Estonia has been set up. The suspected horse was a 5 years old stallion from a horse farm. The horse was depressed and it had respiratory and circulatory impairments. The samples were taken and sent to the laboratory on 6th September. The quarantine and restrictions were set up at the same day. Particular horse is separated from the other horses. There are totally 70 horses in that farm and all other horses appear to be healthy.

The epidemiological investigation has revealed that the horse took part in a competition on 25th August at the FEI European Championships in Gothenburg (21-27). On return to the stud on 28th August the horse had fever $\left(40^{\circ} \mathrm{C}\right)$ and general malaise.

\section{Objective}

To test part of AHS contingency plan: setting up the quarantine and restrictions in the suspected farm.

\section{Expected reaction}

Setting up the quarantine and restrictions in the suspected farm and find out the horse farms in the $20 \mathrm{~km}$ area around the suspected farm. Also trace back the other horses and their movements and connections with the suspected farm.

Estonian competent authority will contact their national horse sector to investigate to what extent horses have been in Gothenburg for the competition. 
7.3.5 Inject 5

Date/time

6/9/2017 at 11:00 (at the CVO meeting).

From (Initiator)

Finland exercise leader.

On behalf of

Chief Veterinary Officer, Finland.

To (receiver/responder)

All CVOs; cc: nbvcg@mast.is

Method (Phone, email, website, other)

Email.

Title of Pegasus 2017 message

This is an exercise, Pegasus 2017: African horse sickness vaccination - Invitation to Skype meeting.

\section{Content}

There is a high possibility that African horse sickness will be suspected or detected in Finland in the near future. Several Finnish horses have been in close vicinity to an infected horse in a competition abroad, possibly contracted the infection and returned to Finland. It is of great importance that all aspects related to vaccination of horses against African horse sickness are being reviewed.

Finland has investigated the possibility to vaccinate and found out, that only 150,000 doses of vaccine can be obtained for the whole region at first stage. More doses will not be available before December 2017.

How should we share the doses within the region in order to control the disease most effectively? Should we try to purchase vaccines together or separately?

Finland will invite experts from the Nordic - Baltic countries to discuss the topic at a Skype meeting starting at 14:00 hours.

\section{Objective}

To initiate discussions on vaccinations against African horse sickness and a common approach to control the disease.

\section{Expected reaction}

Experts will prepare themselves on the topic: Vaccination against African horse sickness. 
7.3.6 Inject 6

Date/time

6/9/2017 at 12:00.

From (Initiator)

Norwegian exercise leader.

On behalf of

Finnish horse trainer.

To (receiver/responder)

Finland; cc: nbvcg@mast.is

Method (Phone, email, website, other)

Email.

Title of Pegasus 2017 message

This is an exercise, Pegasus 2017: Finnish trotting horses in Norway.

\section{Content}

Our horse transport with four Finnish trotting horses is ready to leave from Harstad Travpark (race course) in Northern Norway to go home to Rovaniemi, where they usually are stabled. Two of the horses are registered for the races in Rovaniemi on Sunday.

There is a suspicion of African horse sickness at Olsborg in the county of Troms, and Harstad Travpark and the journey to Finland will be about 100 kilometres from this suspected outbreak.

Can the horses travel home to Finland? Are there any precautions we need to take? Will we have problems with Customs?

\section{Objective}

Information to owners of Finnish horses abroad.

Expected reaction

Information from Evira. 
7.3.7 Inject 7

Date/time

$6 / 9 / 2017$ at $12: 45$.

From (Initiator)

Latvian exercise leader.

On behalf of

Chief Veterinary Officer, Latvia.

To (receiver/responder)

All CVOs; cc: nbvcg@mast.is

Method (Phone, email, website, other)

Email.

Title of Pegasus 2017 message

This is an exercise, Pegasus 2017: Suspicion of African horse sickness in Latvia.

\section{Content}

A suspicion of African horse sickness has been reported in Latvia in a town close to Riga. Epidemiological investigations are on-going.

\section{Objective}

To inform the CVOs in the Nordic Baltic Countries about an African horse sickness Suspicion.

Expected reaction 
7.3.8 Inject 8

Date/time

$6 / 9 / 2017$ at $13: 15$.

From (Initiator)

Danish exercise leader.

On behalf of

Danish Veterinary and Food Administration.

To (receiver/responder)

This is an exercise, Pegasus 2017: Horse semen from Denmark.

Method (Phone, email, website, other)

Email.

Title of Pegasus 2017 message

This is an exercise, Pegasus 2017: Horse semen from Denmark.

Content

The Danish stallion station "Red Horse" in the County of Vejen (DK-6683 Føvling) has sent horse semen to a stud farm in:

- $\quad$ Finland and in Estonia on 23 August 2017.

- $\quad$ Latvia and in Norway on 28 August 2017.

- Sweden and Lithuania on 29 August 2017..

On 6th September 2017, an outbreak of African horse sickness was confirmed in a holding situated 20 kilometres from the Danish stallion station "Red Horse".

Investigations are on-going concerning the places of destination.

Best regards, XXXXX, Animal Health Division, Danish Veterinary and Food Administration

Objective

To give information to Veterinary Authorities in Finland, Estonia, Latvia, Norway, Lithuania and Sweden

Expected reaction

Contact from Veterinary Authorities in FI, EST, LV, NO, LT and SW requesting specific information on the consignments of horse semen from the Danish stallion station "Red Horse". 
7.3.9 Inject 9

Date/time

6/9/2017 at 13:30.

From (Initiator)

Latvian exercise leader.

On behalf of:

Chief Veterinary Officer, Latvia.

To (receiver/responder)

CVO in Sweden; cc: nbvcg@mast.is

Method (Phone, email, website, other)

Email.

Title of Pegasus 2017 message

This is an exercise, Pegasus 2017: Request for information on vector activity.

\section{Content}

For the purpose of making a risk assessment for African horse sickness our epidemiologists would like to receive if possible information on the vector activity during the equine event I Gothenburg from 21- 27 August.

\section{Objective}

To obtain information on vector activity in Gothenburg.

\section{Expected reaction}

Entomologist in Sweden will prepare and submit information on vector activity in Gothenburg. 
7.3.10 Inject 10

Date/time

$6 / 9 / 2017$ at $14: 15$.

From (Initiator)

Danish exercise leader.

On behalf of

EU Commission.

To (receiver/responder)

All CVOs; cc: nbvcg@mast.is

Method (Phone, email, website, other)

Email.

Title of Pegasus 2017 message

This is an exercise, Pegasus 2017: Information on established zones.

Content

The EU Commission requests information on established protection and surveillance zones as a result of the African horse sickness situation in the Nordic and Baltic countries. Several countries have established protection and surveillance zones as a result of the situation. The EU Commission will publish the zones on the internet (homepage), so please send the maps of the established zones as soon as possible.

Please, send the maps to the following Email address: nbvcg@mast.is Thank you in advance.

Best regards, A. Horse, Brussels

Objective

Obtain information on potential overlapping of zones.

Expected reaction

Countries with zones will submit information. 
7.3.11 Inject 11

Date/time

6/9/2017 at 15:00.

From (Initiator)

President of the Nordic-Baltic Veterinary Contingency Group.

On behalf of

The Nordic-Baltic Veterinary Contingency Group.

To (receiver/responder)

All CVOs and leaders of Pegasus 2017 at national level; cc. nbvcg@mast.is

Method (Phone, email, website, other)

Email.

Title of Pegasus 2017 message

This is an exercise, Pegasus 2017; Information on end of Exercise.

Content

Dear Colleagues,

Thank you very much for your participation in and contributions to Pegasus 2017. The international exercise stops now at 15:00 hours (GMT + 2)

Best wishes for potential on-going aspects of the exercise and for the evaluation component of the exercise.

Please, inform your Departments/Divisions that the international exercise has ended.

Best regards, Anna Huda, Animal Health Division, Danish Veterinary and Food Administration.

\section{Objective}

To terminate the international aspects of Pegasus 2017.

Expected reaction

Countries with will stop the international aspects of the exercise; but may continue the National aspects. 


\subsection{Icelandic scenario}

Time

6 September 2017 8:00-12:00 and 7 September 8-12:00 (GMT).

Two half day exercises (on a national level).

\section{Participants}

- $\quad$ Sigríður Björnsdóttir, Veterinary officer for horse diseases.

- Sigurborg Daðadóttir, CVO.

- $\quad \mathrm{NN} / \mathrm{NN}$, District Veterinarian at XX-district (one or two).

- Veterinary team at Keldur, Institute for Experimental Pathology. (preparing samples etc.).

\section{Exercise leaders}

- Sigríður Gísladóttir, NBVCG representative.

- Auður Lilja Arnpórsdóttir, Veterinary officer for epidemiology and contingency planning.

\section{Goal, description}

This exercise will be a part of the international exercise "Pegasus", which has a focus on the exotic vector borne disease, African horse sickness. As the vector for this disease (Culicoides spp.) does not live in Iceland and the import of horses is not permitted, there is a very small chance of the disease spreading to Iceland. Therefore, it is also very unlikely that horses from the scene of the Pegasus exercise in Scandinavia would get a chance to spread the disease to Iceland. Direct injects or participation is therefore not feasible.

Our goal for the national exercise Pegasus - Iceland is to test the contingency plan for horse diseases, with a suspicious link to the international events of Pegasus. The exercise will test the abilities of Mast employees to react to a suspicion of a serious, exotic disease in horses, with symptoms from airways. The exercise will go as far as preparing the establishment of zones and other epidemiologic measures, sampling and preparation of samples, and samples will be sent to a laboratory abroad for disease verification. This will be on Day 1 . On Day 2 there will be an inject to the national exercise from the exercise leaders, telling the participants that two days have passed since the samples were sent and we have received preliminary results from the laboratory that the disease in question is Equine Influenza. Equine Influenza has never been found in Iceland. It is still unsure if the second day will be a desk rehearsal or a physical exercise - establishing zones etc. That will be based on funding. 


\subsection{Information Note to Players}

\section{Introduction}

An African horse sickness simulation exercise will be conducted in the Nordic-Baltic countries and the players during the exercise will be staff members of the National Veterinary Administrations and stakeholders in the horse sector involved in animal health contingency planning.

The scenario for the exercise includes that the African horse sickness virus has been introduced to one or more of the Nordic-Baltic Countries. The entrance of the virus may be epidemiologically linked to an equine event in Gothenburg, where horses from many countries have been competing. The simulation exercise will start in the morning of Wednesday 6th September 2017 and run for a period of $1-2$ days. The duration of the exercise in individual countries depends on the decision of the National Veterinary Administration.

Players

The players in the exercise are persons who during animal disease emergencies are designated to take part in development of and the application of measures to prevent, control and eradicate exotic infectious diseases including the vector borne viral horse disease: African horse sickness. In brief: Players are identified on the basis of their respective professional functions and roles rather than individuals. In this context it should be mentioned that an exercise offers an opportunity for backup staff as well as principals to practice key emergency roles and decision making.

Legislation and a contingency plan covering control and eradication of African horse sickness is available to all players and it is anticipated that players will respond to a simulated situation as they would in a real emergency.

\section{Directing staff}

The Directing staff of the simulation exercise will make use of a script with information on the scenario and timetable for injects related to all inter-Nordic-Baltic activities and of a script covering activities at National level.

\section{Evaluation}

The aim and objectives of the exercise include testing the National African horse sickness contingency plan and to see how information can be shared by the NordicBaltic Veterinary Administrations and relevant stakeholders during an emergency situation.

For the purpose of improving legislation and contingency plans the players will receive questionnaires and participate in meetings, where potential improvements can be discussed. 



\section{Evaluation}

\subsection{Methodology}

An independent evaluator was appointed for the international aspects of the exercise, and each participating country appointed one or more national evaluators. The national evaluators evaluated both the international and the national aspects of the exercise from their country's perspective.

The national evaluators liaising with the Independent evaluator were:

Table 8: Exercise Pegasus National Evaluators

\begin{tabular}{|c|c|c|}
\hline Country & Name & Email \\
\hline Sweden & Malte Ahlström & Malte.Ahlstrom@jordbruksverket.se \\
\hline Sweden & Anja Bertilsson & Anja.Bertilsson@jordbruksverket.se \\
\hline Estonia & Hele-Mai Sammel & hele.sammel.@vet.agri.ee \\
\hline Denmark & Lone Jannok Porsbo & lojpo@fvst.dk \\
\hline Norway & Janne-Britt Krakhellen & jannebrittkrakhellen@outlook.com \\
\hline Finland & Juha Kalander & juha.kalander@evira.fi \\
\hline Latvia & Martiņš Seržants & Martins.Serzants@pvd.gov.lv \\
\hline
\end{tabular}

A participant's questionnaire was provided for each participant and each national evaluator collated the individual participant's questionnaires into a national evaluator questionnaire for each country. The national evaluator questionnaires were returned to the independent evaluator for collation.

The independent evaluator attended the exercise in Sweden and was present for the Skype conferences.

The independent evaluator was to be copied international emails sent between countries via a group Email nbvcg@mast.is. However, the technology failed, and the independent evaluator only received international emails which were also copied personally to him; there were very few. The independent evaluator's commentary on the collated national evaluator questionnaires is set out below.

\subsection{Analysis of National Evaluator Questionnaires}

\subsubsection{Technical Aspects}

A summary and collation of returns from the national evaluators may be found beginning at Table 9, page51. It is worth noting that most countries would confirm on the basis of an RT-PCR test, however, Norway would wait for confirmatory tests performed by the EU Community Reference Laboratory. Rendering was the method of 
choice for disposal of carcasses in most countries. Most countries commented that equine registers required by EU legislation were inadequate to determine location and number of animals in a Protection Zone or Surveillance Zone.

\subsubsection{Communications}

For international communication countries used email for notifications (injects) and telephone by Sweden. The most effective communication tool for sharing information and agreeing a common approach was Skype.

Other aspects of communications are summarised in Table 13-15 on pages 52-53. Most countries agreed that while Skype was the most effective tool for communication between countries there were problems with technical set-up which delayed the start of meetings. It was felt that there was inadequate exchange of information before the Skype meetings. Had information been exchanged beforehand the meetings would have been even more meaningful. It may have been the case that the independent evaluator did not see all communications between countries the impression gained from the Skype meetings and the national evaluators was that this was an area for improvement. It was felt that countries should have been proactive in disseminating information rather than waiting to be asked for the information.

The Skype meetings were well run having a good chair for each and an agenda. A summary note of the first meeting was produced. There was insufficient time to produce a note of the second meeting. The first meeting appeared to be the first occasion on which full information was shared between countries.

The second meeting was a combination of two planed Skype meetings, one on communication and one on vaccination. The meetings were combined because of time pressure. The second meeting accomplished more. Because the scenario had developed there was a common understanding that with very large protection and surveillance zones, even with equine registers required by Community law, it was impossible for the Competent Authorities to know where horses were resident. See Figure 4: Map showing the extent of the Swedish Protection and Surveillance Zones, page 56. In addition, the requirement in Directive 92/35/EEC that all such premises should have a veterinary visit was practically impossible to achieve and would be a nugatory effort. A common approach to information to be provided to the public was agreed. There was a common concern about the use of attenuated live vaccines (reversion to virulence, reassortment). It was agreed that given the time of the year there would only be two or three weeks before the vector season closed and as the virus did not overwinter the disease would naturally die out without the use of vaccine. In Denmark, the vector season was longer and usually ended around the 1st December. 


\subsubsection{Stakeholders and Participants}

Table 16: Stakeholders and Participant Scores, on page 53, gives the numbers of stakeholders and participants attending the exercise and summarises their views. Three countries invited stakeholders to the exercise and in two countries the stakeholders took part in the decision making.

The value of stakeholders attending exercises can be illustrated by the comments of stakeholders attending the Norwegian exercise set out in the see text below.

It can be seen from that the participants scored the experience of the exercise very highly on a scale of 1 to 5 where 1 is poor and 5 is excellent. A flavour of comments from participants can be seen from the Danish participants' comments below.

\subsubsection{Future Training of Personnel}

The summaries of the national evaluator returns are shown in Table 17: Future Training on page 54, Figure 2: Field Staff Training Preferences on page 55, Figure 3: NDCC Staff Training Preferences on page 55 and Table 18: Future Training of Personnel on page 56. Most felt that some further training is necessary and the preferred methods of training by both field staff and NDCC staff were exercises and written information was the least preferred method of training. E-learning was thought to be valuable.

\subsubsection{Norwegian Stakeholder Comments}

- The Norwegian Horse Center, Norsk Hestesenter.

- The Norwegian Trotters Association, Det Norske Travselskap.

- The Federation of Norwegian Riders, Norsk Rytterforbundet.

- The Norwegian federation of meat and poultry producers, Animalia.

- The Norwegian Veterinary Association, Den Norske Veterinærforening.

"The main concern of the stakeholders was the lack of/delays in the competent authority's information targeted at horse owners, stakeholders and private practitioners; what should/could the different stakeholders contribute in an outbreak situation. The horse associations called for more information/clearer communications from the CA regarding:

Affected areas, information on the geographical borders of the different zones and what information to provide, if any, to horse owners in the different zones

How to deal with planned events (on day 2 the NFSA issued a stand still regulation banning all horse gatherings)

The associations were also concerned of the long-term effect on their respective sports in case of vaccination.

Although not directly involved in the decision-making, the associations' advice to CA was to ban organizing horse events in affected zones, and hey advised against vaccination.

The association for producing animals in Norway called for clearer communication to the industries - what, if anything, should they be doing, e.g. in relation to transport of live animals.

The Veterinary association called for clearer information regarding Private Practitioner's potential role and responsibility in an outbreak, e.g. concerning vaccination/no vaccination." 


\subsubsection{Danish Participant Comments}

"The general comments were that the participants were very pleased with being put out of their normal comfort zone and work with in a new area (a horse disease).

Participants with long experience in outbreak management enjoyed the exercise but did not add new learning. Participants with no or small experience learned a lot of crisis management and contingency planning. In Denmark, we also had veterinary officers working in the field, and they gained new knowledge in handling a situation among horse owners, which are different from professional farmers."

\subsection{Principal Lessons and Recommendations}

The broad international objectives of the exercise were met with some lessons to be learnt.

Although the independent evaluator did not have access to all communications between countries the impression gained was that these were few. The first Skype conference was the first occasion when information was fully shared. If information had been shared before the Skype meeting, there would have been even more benefit to the discussions.

It is recommended that countries are more proactive in sharing information particularly with neighbouring countries. It should not be necessary for countries to request such information.

The Skype meetings were very effective at sharing information, reaching a common understanding, particularly on vaccination and the provision of information to the public. However, there was considerable delay in setting up the meetings principally because of technical difficulties.

It is recommended that technical problems are resolved well before any meetings; that staff using video conferencing is trained in its use; that technical staff set up and test communication five minutes before the start of the meeting and that meetings start promptly on time. In the real world, such meetings will be attended by senior staff - their time is precious, particularly in an outbreak situation, and should not be wasted. For international Skype meetings there should be a formal agenda with objectives for each item. If there are joint decisions to be made, then persons participating in the conference should have delegated authority to agree the decision.

It is recommended that all countries develop a communications strategy as part of their contingency plans including information to horse owners and veterinary practioners which can be published on the web in the event of an outbreak.

Some countries invited stakeholders to attend the exercise; this is good practice.

It is recommended that all countries consider the use of stakeholders to develop their contingency plans and to attend exercises and test the plans. Stakeholders may also add value to expert groups; they give an insight on how the industry works, animal movements, their scale and seasonality. It is a two-way process because stakeholders can understand the Competent Authority's requirements in controlling any outbreak and pass this on to the livestock keepers they represent. 
With very large protection and surveillance zones (see Figure 4: Map showing extent of Swedish Protection and Surveillance Zones, page 56), even with equine registers required by community law, it was impossible for the Competent Authorities to know where horses were resident. In addition, the requirement in Directive 92/35/EEC that all such premises should have a veterinary visit was practically impossible to achieve and would be a nugatory effort.

Directive $92 / 35 / \mathrm{EEC}$ is clearly out of date. Tertiary legislation on the control of AHS will be brought forward under the new Animal Health Law Regulation (EU) 2016/429.

It is recommended that the difficulties observed in exercise Pegasus with respect to large control zones and the practicality of veterinary visits to horse premises are brought to the attention of the Commission through SCoPAFF.

\subsection{Summary Tables of National Evaluator Returns}

\subsubsection{Technical Aspects}

Table 9: Investigation and Confirmation

\begin{tabular}{|c|c|c|c|c|}
\hline Country & $\begin{array}{l}\text { Response time to } \\
\text { first suspicion }\end{array}$ & $\begin{array}{l}\text { Duration of } \\
\text { investigation }\end{array}$ & Who confirms disease & Basis of confirmation \\
\hline Denmark & 1-2hrs & 1-2hrs & CVO & RT-PCR \\
\hline Estonia & 1-2hrs & N/A & DG VFB & RT-PCR Virus isolation \\
\hline Finland & $\mathrm{N} / \mathrm{A}$ & N/A & $\mathrm{N} / \mathrm{A}$ & RT-PCR confirmatory test by EURL \\
\hline Latvia & 3-5hrs & 3-5hrs & Official Veterinarian & RT-PCR \\
\hline Norway & 1 -2hrs & 3-5hrs & Head Office of NFSA & On basis of confirmatory test by EURL \\
\hline Sweden & N/A & N/A & Swedish Board of Ag. & RT-PCR \\
\hline
\end{tabular}

Table 10: National Reference Laboratory Capability/Capacity

\begin{tabular}{|c|c|c|c|c|c|c|}
\hline & DNK & EST & FIN & LVA & NOR & SWE \\
\hline Week 1 capacity & & Samples sent to UK & & & & \\
\hline AHS Ag & 2000 & & & $\checkmark$ & $\checkmark$ & \\
\hline AHS Ab & 25000 & & & $\checkmark$ & $\checkmark$ & \\
\hline Virus Isolation & N/A & & & $\mathrm{N} / \mathrm{A}$ & $\checkmark$ & \\
\hline
\end{tabular}

Table 11: Availability of Livestock Data

\begin{tabular}{lllllll} 
& DNK & EST & FIN & LVA & NOR & SWE \\
\hline PZ & At Confirmation & On suspicion & N/A & At Confirmation & Within 2ok radius 24hrs & $>12 \mathrm{hrs}$ \\
SZ & At Confirmation & At Confirmation & N/A & At Confirmation & & $>12 \mathrm{hrs}$ \\
\hline
\end{tabular}

Note: Most countries agreed that Equine Registers required by EU law were inadequate to determine the location of horses in the PZ and SZ 
Table 12: Disposal

\begin{tabular}{lcccccc} 
& DNK & EST & FIN & LVA & NOR & SWE \\
Burial on Farm & $X$ & $O$ & $\checkmark$ & $X$ & $\checkmark$ & N/A \\
Burning on Farm & $X$ & $O$ & & $X$ & & N/A \\
Mass burial off Farm & $X$ & $O$ & $\checkmark$ & $X$ & & N/A \\
Render in Country & $\checkmark \checkmark$ & $\checkmark \checkmark$ & $\checkmark \checkmark$ & $\checkmark$ & $\checkmark \checkmark$ & N/A \\
Render in another country & $X$ & $X$ & & $\checkmark \checkmark$ & & N/A \\
Incinerate in Country & $\checkmark$ & $O$ & $\checkmark$ & $\checkmark$ & $\checkmark \checkmark$ & N/A \\
Incinerate in another Country & $X$ & $X$ & & $X$ & & \\
\hline
\end{tabular}

Note: $\quad \checkmark \checkmark$ Method of choice

O Not very Acceptable

$\checkmark$ Acceptable

X Not Acceptable

\subsubsection{Communication}

For international communication countries used email for notifications (injects) and telephone by Sweden. The most effective communication tool for sharing information and agreeing a common approach was Skype.

Table 13: Communication

\begin{tabular}{|c|c|c|c|c|c|c|}
\hline & DNK & EST & FIN & LVA & NOR & SWE \\
\hline $\begin{array}{l}\text { Who communicates with other } \\
\text { Nordic Baltic Countries }\end{array}$ & CVO & CVO & CVO & $\begin{array}{l}\text { Senior expert for } \\
\text { Pegasus }\end{array}$ & CVO & CVO \\
\hline $\begin{array}{l}\text { How often did you update N-B } \\
\text { Countries }\end{array}$ & Hourly & Immediate & $\begin{array}{l}\text { No } \\
\text { outbreaks }\end{array}$ & $\begin{array}{l}\text { Constrained by } \\
\text { exercise }\end{array}$ & $\begin{array}{l}\text { Email and Skype } \\
\text { meetings }\end{array}$ & Daily \\
\hline $\begin{array}{l}\text { Who is responsible for } \\
\text { communicating with OIE and } \\
\text { EU Commission }\end{array}$ & CVO & CVO & CVO & $\begin{array}{l}\text { Senior expert for } \\
\text { Pegasus }\end{array}$ & CVO & CVO \\
\hline
\end{tabular}

Table 14: Communications

\begin{tabular}{|c|c|c|c|c|c|c|}
\hline & DNK & EST & FIN & LVA & NOR & SWE \\
\hline Comms Strategy as part of $\mathrm{CP}$ & Yes & No & Yes & No & Yes & Yes \\
\hline Pre-prepared AHS website & No & No & No & No & Yes & Yes \\
\hline $\begin{array}{l}\text { Pre-prepared information for media and keepers } \\
\text { Leaflets } \\
\text { Books }\end{array}$ & No & No & Yes & Yes & No & Yes \\
\hline Web pages & & & $\checkmark$ & & & $\checkmark$ \\
\hline Advisory leaflet & & & & $\checkmark$ & & \\
\hline Social Media & & & & $\checkmark$ & & \\
\hline Up to date Communications directory & Yes & Yes & Almost up to date & Yes & Yes & Yes \\
\hline
\end{tabular}


Table 15: Communications

\begin{tabular}{|c|c|c|c|c|c|c|}
\hline & DNK & EST & FIN & LVA & NOR & SWE \\
\hline $\begin{array}{l}\text { Communication between } \\
\text { NDCC and N-B Countries }\end{array}$ & Excellent & Good & Good & Good & Good & Average \\
\hline What went well? & Skype & Skype & Skype & $\begin{array}{l}\text { Sharing } \\
\text { infomation } \\
\text { sharing }\end{array}$ & Skype & Skype \\
\hline What could be improved? & Skype setup & Skype setup & $\begin{array}{l}\text { More } \\
\text { detailed } \\
\text { Information }\end{array}$ & & $\begin{array}{l}\text { Variation on } \\
\text { housing } \\
\text { horses } \\
\text { policy }\end{array}$ & $\begin{array}{l}\text { Information } \\
\text { sharing } \\
\text { before } \\
\text { conferences }\end{array}$ \\
\hline Other Comments & $\begin{array}{l}\text { Injects in } \\
\text { compressed } \\
\text { time frame }\end{array}$ & $\begin{array}{l}\text { Comms } \\
\text { strategy to } \\
\text { be part of } \\
\text { CP }\end{array}$ & & & $\begin{array}{l}\text { Did exercise } \\
\text { test real } \\
\text { world } \\
\text { events? }\end{array}$ & \\
\hline
\end{tabular}

Table 16: Stakeholders and Participant Scores

DNK EST FIN LVA NOR SWE

Stakeholders invited

No of stakeholder observers

No of stakeholder decision takers

Stakeholder comments

No of participants from CA

How many participants completed evaluation

$\begin{array}{rrrrrr}\text { Yes } & \text { No } & \text { Yes } & \text { No } & \text { Yes } & \text { No } \\ 4 & 0 & 0 & 0 & 5 & \\ 2 & 0 & 2 & 0 & 0 & \\ \text { Yes } & \text { No } & \text { Yes } & \text { No } & & \\ 68 & 7 & 12 & 2 & 300 & 14 \\ 34 & 6 & 10 & 1 & 146 & 13\end{array}$

(Mean evaluation scores $1=$ poor $5=e x c e l l e n t)$

Did exercise meet networking and shared experiences expectations

Relevant for work

Had prerequisite knowledge

Level of exercise

Improved knowledge of Contingency planning

Enhanced skills on horse diseases

Information received before exercise

How good was the scenario

Management of exercise

Overall assessment

\begin{tabular}{rrrrr}
3.9 & 4.1 & 4 & 3.5 & 3.7 \\
4.8 & 4.1 & 4.5 & 4.5 & 4.5 \\
4.9 & 4.5 & 4.3 & 3.5 & 4.2 \\
4.2 & 4.1 & 3.9 & 4 & 3.9 \\
4 & 4 & 4.3 & 4.5 & 3.2 \\
4.8 & 4.5 & 4.2 & 3.75 & 3.7 \\
4 & 4.5 & 4 & 4 & 4.2 \\
4.3 & 4.1 & 4.1 & 4.75 & 4 \\
4.1 & 4.3 & 3.9 & 4.75 & 4.3 \\
4.3 & 4.1 & 4 & 4 & 4 \\
\hline
\end{tabular}


Table 17: Future Training

\begin{tabular}{|c|c|c|c|c|c|c|}
\hline & DNK & EST & FIN & LVA & NOR & SWE \\
\hline $\begin{array}{l}\text { Duration of } \\
\text { exercise }\end{array}$ & About right & About right & About right & $\begin{array}{l}\text { About } \\
\text { right }\end{array}$ & About right* & Too short \\
\hline Tasks in exercise & $\begin{array}{l}\text { Different but } \\
\text { challenging to } \\
\text { excellent }\end{array}$ & $\begin{array}{l}\text { Tasks realistic, } \\
\text { could have been } \\
\text { more challenging }\end{array}$ & Excellent & Excellent & Excellent & $\begin{array}{l}\text { Different but } \\
\text { challenging }\end{array}$ \\
\hline $\begin{array}{l}\text { Trained for crisis } \\
\text { management }\end{array}$ & $\begin{array}{l}\text { Yes with } \\
\text { some } \\
\text { reservations }\end{array}$ & Yes very well & $\begin{array}{l}\text { Yes with } \\
\text { some } \\
\text { reservations }\end{array}$ & Not really & $\begin{array}{l}\text { Yes with } \\
\text { some } \\
\text { reservations }\end{array}$ & $\begin{array}{l}\text { Yes with } \\
\text { some } \\
\text { reservations }\end{array}$ \\
\hline $\begin{array}{l}\text { How much more } \\
\text { training of field } \\
\text { staff }\end{array}$ & $\begin{array}{l}\text { A number of } \\
\text { days }\end{array}$ & One day & One day & $1 / 2$ day & $\begin{array}{l}\text { A number of } \\
\text { days }\end{array}$ & $\mathrm{N} / \mathrm{A}$ \\
\hline $\begin{array}{l}\text { How much more } \\
\text { training for } \\
\text { NDCC staff }\end{array}$ & One day & One day & One day & $1 / 2$ day & $\begin{array}{l}\text { A number of } \\
\text { days }\end{array}$ & $\mathrm{N} / \mathrm{A}$ \\
\hline
\end{tabular}

Note: *The Norwegian exercise lasted two days 
Figure 2: Field Staff Training Preferences

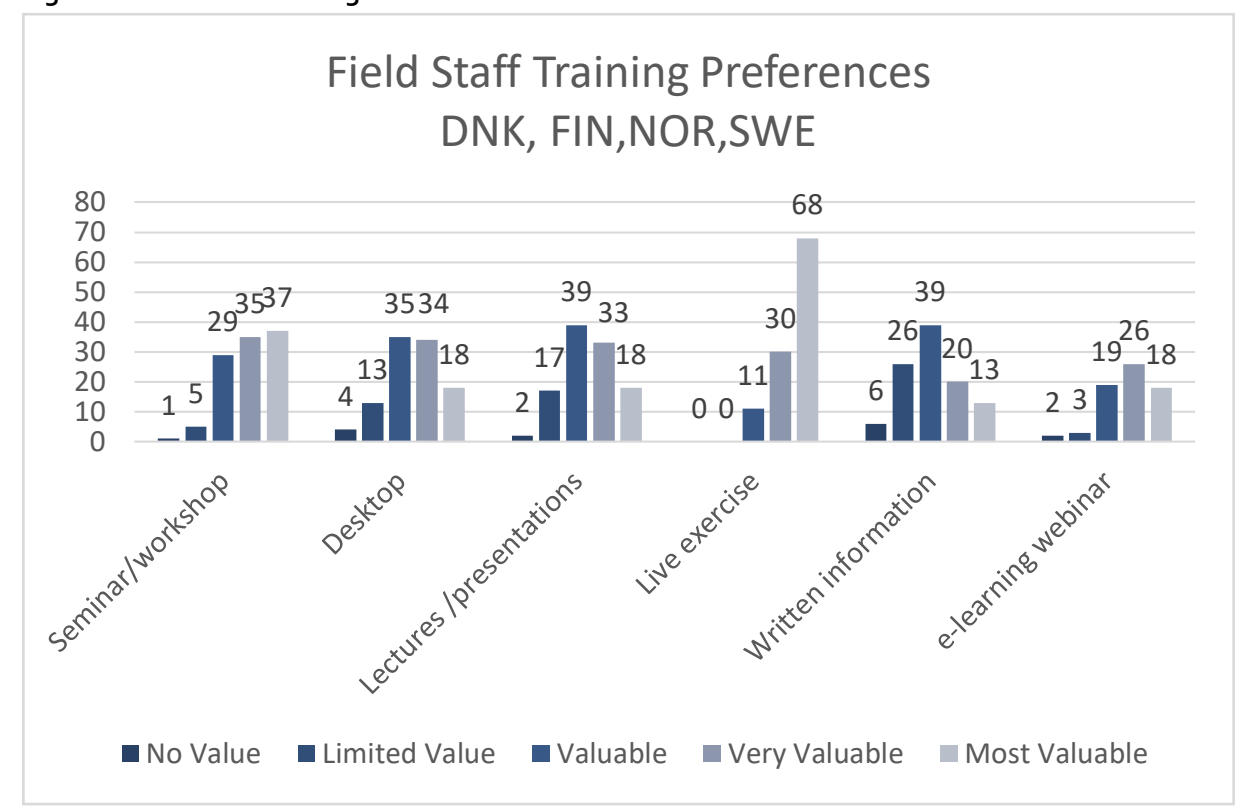

Figure 3: NDCC Staff Training Preferences

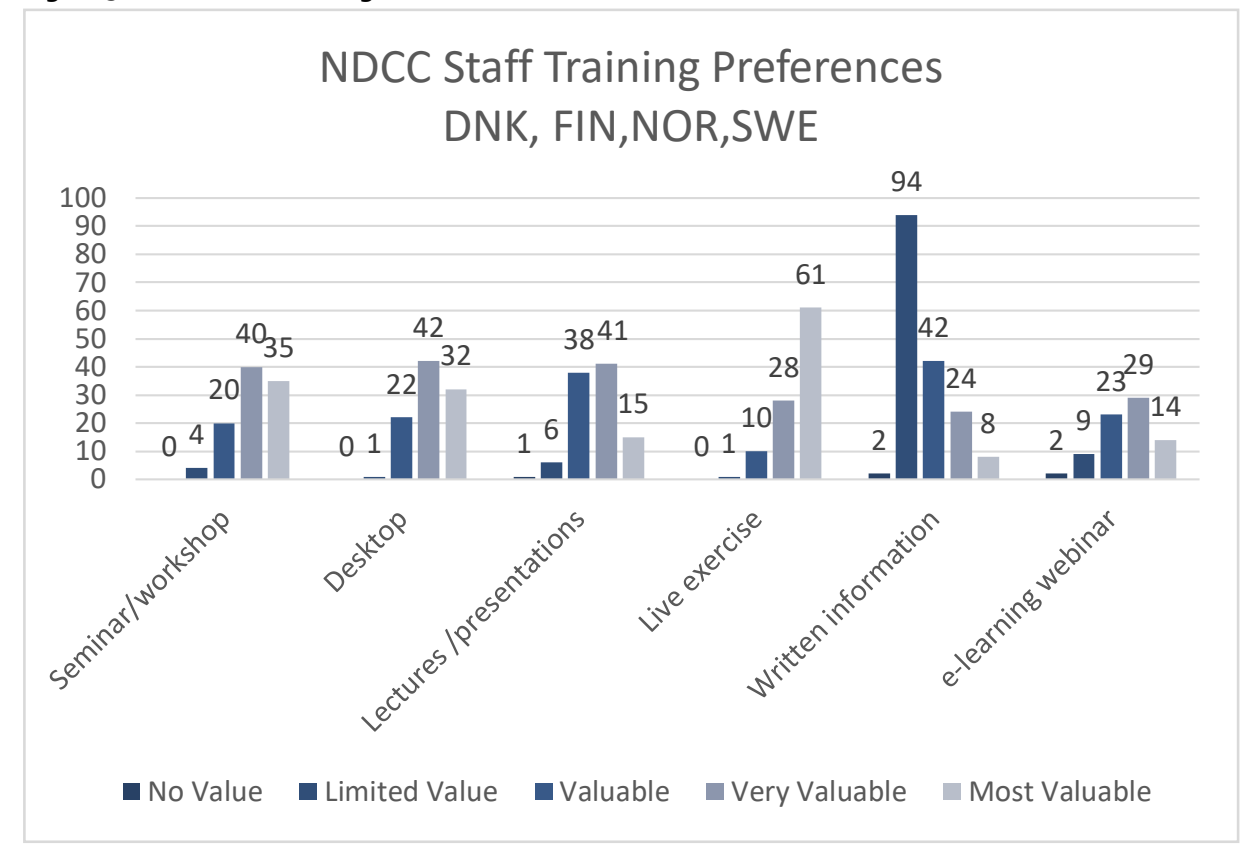


Table 18: Future Training of Personnel

\begin{tabular}{|c|c|c|c|c|c|c|}
\hline & DNK & EST & FIN & LVA & NOR & SWE \\
\hline Objectives met & Yes & Yes & Yes & & Yes & No \\
\hline If not met, why not? & & & & $\begin{array}{l}\text { Part of exercise } \\
\text { postponed }\end{array}$ & & $\begin{array}{l}\text { Not all areas met } \\
\text { targets }\end{array}$ \\
\hline What went well? & Skype conference & $\begin{array}{l}\text { Participants knew } \\
\text { their roles }\end{array}$ & $\begin{array}{l}\text { Skype } \\
\text { meeting }\end{array}$ & $\begin{array}{l}\text { Positive } \\
\text { communication }\end{array}$ & Skype meetings & Skype meetings \\
\hline $\begin{array}{l}\text { What could be } \\
\text { improved? }\end{array}$ & $\begin{array}{l}\text { Time limitation to } \\
\text { complete tasks }\end{array}$ & $\begin{array}{l}\text { More practical tasks } \\
\text { to involve field staff }\end{array}$ & & & $\begin{array}{l}\text { Coordination of } \\
\text { communication. } \\
\text { Communication of } \\
\text { large zones crossing } \\
\text { national boundaries }\end{array}$ & $\begin{array}{l}\text { National Targets to } \\
\text { be reviewed }\end{array}$ \\
\hline $\begin{array}{l}\text { Change AHS } \\
\text { Contingency Plan? }\end{array}$ & Not decided & $\begin{array}{l}\text { Yes complete } \\
\text { revision to include } \\
\text { comms strategy }\end{array}$ & No & $\begin{array}{l}\text { Yes update } \\
\text { required }\end{array}$ & No & N/A \\
\hline Other comments & $\begin{array}{l}\text { Participants had } \\
\text { no experience of } \\
\text { disease outbreaks } \\
\text { in horses }\end{array}$ & $\begin{array}{l}\text { Need to include } \\
\text { exercises for field } \\
\text { staff }\end{array}$ & & $\begin{array}{l}\text { Willing to take } \\
\text { part in other } \mathrm{N} \text { - } \\
\text { B exercises }\end{array}$ & $\begin{array}{l}\text { Preprepare zones to } \\
\text { develop the scenario }\end{array}$ & $\begin{array}{l}\text { Exercise should last } \\
\text { two days }\end{array}$ \\
\hline
\end{tabular}

Figure 4: Map showing extent of Swedish Protection and Surveillance Zones

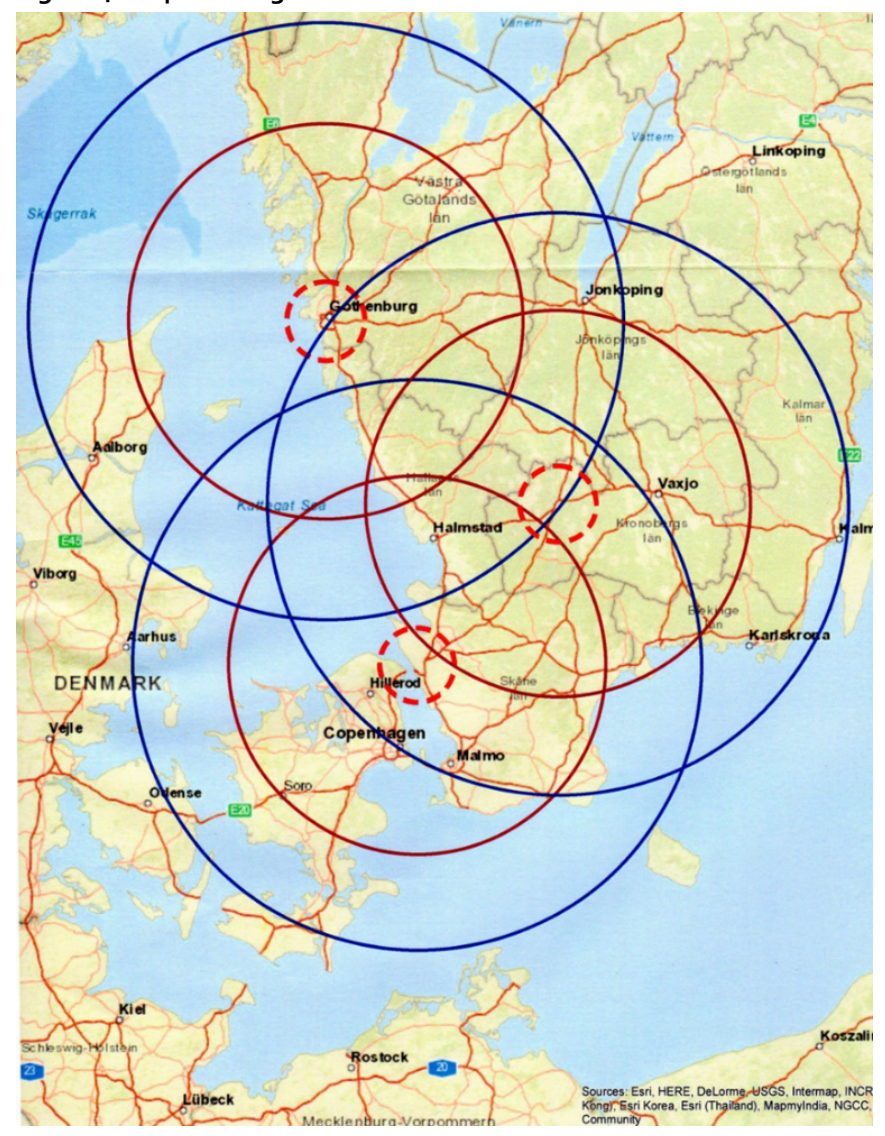




\section{References}

European Centre for Disease Control. (2014). Handbook on Simulation

Exercises in EU Public Health Settings.

European Commission. (1982). Council Directive 82/894/EEC of 21 December 1982 on the notificaiton of animal diseases within the EU (Vols. OJ. No. L.378, 321982 p.58).

European Commission. (1992). Council Directive 92/35/EEC of 29th April 1992 laying down rules and measures to combat African Horse Sickness OJ. No. l. 157, 10.6.1992.

Liljenstolpe, C. (2009). Horses in Europe. Swedish University of Agricultural Science (SLU).

OIE. (n.d.). Terrestrial Animal Health Code. Paris: OIE. 



\section{Sammendrag}

De Nordiske og Baltiske lande er frie for de meget smitsomme sygdomme, som forårsager problemer for hestesektoren i mange egne af verden. Med henblik på at opretholde denne privilegerede status er det nødvendigt, at veterinære administrationer, hesteejere og praktiserende dyrlæger er årvågne og tænker på eksotiske sygdomme ved udbrud af hestesygdomme. Alle de Nordiske og Baltiske lande har i forbindelse med øgede beskyttelsesforanstaltninger mod eksotiske sygdomme udarbejdet og vedtaget beredskabsplaner for afrikansk hestepest, en virus sygdom, som overføres med insekter. Et meget værdifuldt instrument for afprøvning af beredskabsplaner er øvelser, der simulerer sygdomsudbrud, og en Nordisk-Baltisk beredskabsøvelse med afrikansk hestepest blev afholdt i september 2017. Formålet med øvelsen omfattede:

- at afprøve de eksisterende afrikansk hestepest beredskabsplaner i de NordiskBaltiske lande;

- at yderligere udvikle det kommunikationssystem, der er etableret imellem veterinære administrationer i de Nordiske og Baltiske lande;

- at forbedre kendskabet til afrikansk hestepest og sygdomsbekæmpelses metoder;

- at forbedre kommunikationen imellem de Nordiske og Baltiske lande i krisesituationer og i forbindelse med kommunikationen til offentligheden sikre, at den er korrekt, klar, relevant og ensartet.

Afrikansk hestepest (AHP) blev valgt til beredskabsøvelsen, idet AHP med hensyn til det infektiøse agens og overførsel via insekter i høj grad ligner bluetongue (BT), en virussygdom hos drøvtyggere, som kun overføres via insekter, og som siden 2007 har forårsaget store problemer i flere lande i Nordeuropa herunder Danmark. Siden 2007 er forekomsten af BT også rapporteret fra Norge og Sverige.

Beredskabsøvelsen blev planlagt af den Nordisk-Baltiske veterinære beredskabs gruppe, og øvelsen blev afholdt den 6.september 2017. Øvelsen omfattede adskillige aktiviteter relateret til:

- Inter Nordisk-Baltiske emner.

- Nationale emner.

En uafhængig evaluator blev udpeget til at varetage evalueringen af de Inter NordiskBaltiske aspekter af beredskabsøvelsen, og hvert deltagerland udpegede en eller flere 
evaluatorer til at varetage evalueringsopgaver, som omfattede både Nordisk-Baltiske forhold og forhold, der vedrørte nationale aspekter af øvelsen.

Evalueringen behandlede kommunikation i forbindelse med mistanke om og bekræftelse af sygdom, tekniske forhold vedrørende kontrol og bekæmpelse af AHP, engagement af samarbejdspartnere, indtryk af øvelsesdeltagere og fremtidige uddannelser af personel. Resultatet af evalueringen fremhævdede værdien af at afholde beredskabsøvelser, der involverer flere lande, og at oplysninger om det enkelte lands kommunikationsstrategi skal være en integreret del af beredskabsplaner. 


\section{Acknowledgements}

The organizers of the simulation exercise "Pegasus 2017" would like to convey their thanks to the Nordic Council of Ministers for the financial support made available for the preparation, conduct and evaluation of the African horse sickness simulation exercise and to players and stakeholders for contributions to the success of the exercise.

With regard to the evaluation of the exercise the independent evaluator would like to thank all the national evaluators for their timely and detailed contributions on the national evaluation forms. Without their contributions this report would not have been possible. Furthermore the evaluator would like to thank staff of the Swedish Board of Agriculture for making me most welcome in Jönköping during the exercise, for their generous hospitality and the opportunity to see a small part of their beautiful country.

\subsection{The Nordic-Baltic Veterinary Contingency Group}

The Nordic -Baltic Veterinary Contingency Group (N-B VCG) consist of representatives of the National Veterinary Administrations from Denmark, Estonia, Finland, Iceland, Latvia, Lithuania, Norway and Sweden.

Since the creation of the N-B VCG in 2006, the work of the group has been engaged in contingency planning and conducted a number of workshops, seminars and simulation exercises covering diseases such as: foot and mouth disease, avian influenza, African swine fever, bluetongue, West Nile fever and viral haemorrhagic septicaemia in trout.

All activities are carried out within the framework of allocations made available from the Nordic working group for microbiology and animal health/animal welfare. 
11.1.1 Organisational Chart showing the link between the Nordic working group for microbiology and animal health/animal welfare and the N-B VCG

Figure 5: Organisational Chart

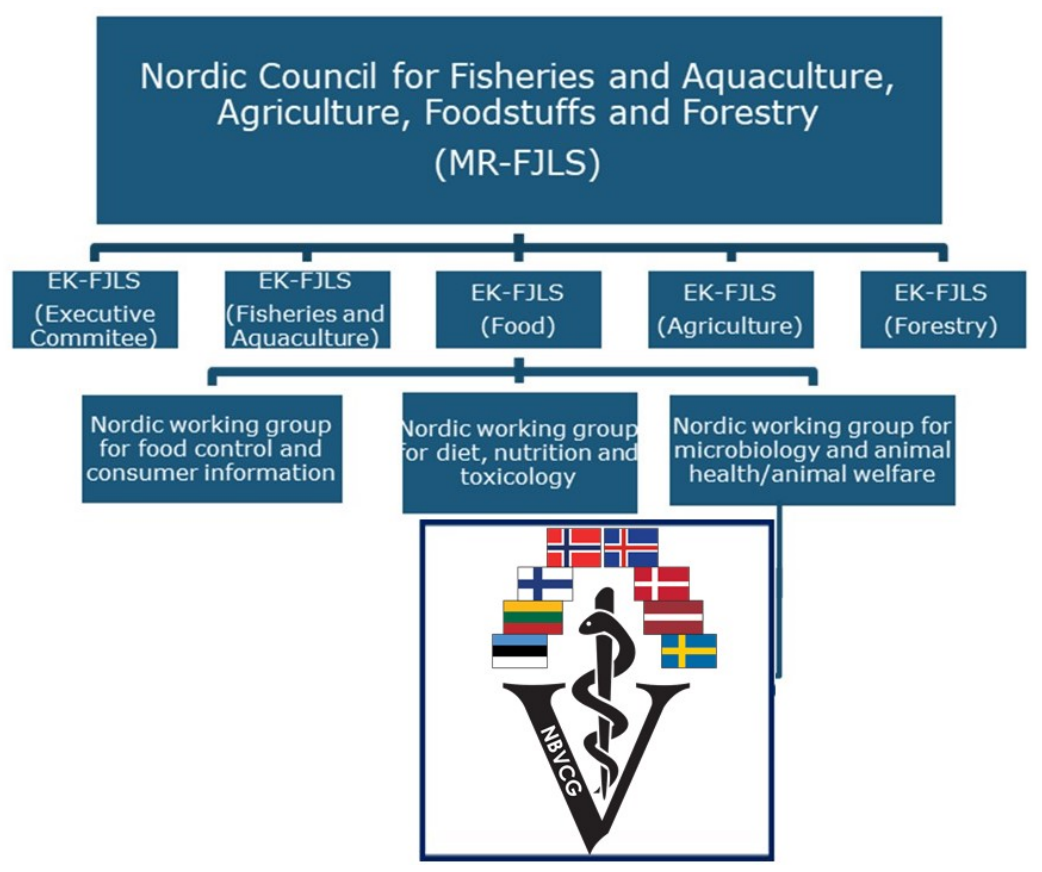


Nordic Council of Ministers

Nordens Hus

Ved Stranden 18

DK-1061 Copenhagen

www.norden.org

\section{Exercise Pegasus 2017}

African horse sickness (AHS) is an acute insect-borne viral disease of horses and other equines causing depression, respiratory and circulatory impairment. The mortality rate may approach $100 \%$. The disease is transmitted by midges. In 2007-2009 midges caused the spread of bluetongue in cattle and sheep in Northern Europe. The midges are also the main vector and transmitter of AHS and the disease may occur in horses in the Nordic Baltic region during summer or early autumn. Contingency plans covering AHS have been adopted by the Nordic Baltic countries. This report provides information on the preparatory work and the conduct of a simulation exercise. The aim of the exercise included testing of National AHS contingency plans and of the communication systems established between veterinary authorities in the Nordic and Baltic countries for animal disease emergencies. 